\title{
Influence of broccoli extract and various essential oils on performance and expression of xenobiotic- and antioxidant enzymes in broiler chickens
}

\author{
Kristin Mueller, Nicole M. Blum, Holger Kluge and Andreas S. Mueller* \\ Institute of Agricultural and Nutritional Sciences, "Preventive Nutrition Group", Martin Luther University Halle Wittenberg, \\ Von Danckelmann Platz 2, D-06120 Halle (Saale), Germany
}

(Submitted 16 March 2011 - Final revision received 26 August 2011 - Accepted 3 October 2011 - First published online 16 November 2011)

\begin{abstract}
The aim of our present study was to examine the regulation of xenobiotic- and antioxidant enzymes by phytogenic feed additives in the intestine and the liver of broilers. A total of 240 male Ross-308 broiler chickens ( $1 \mathrm{~d}$ old ) were fed a commercial starter diet for 2 weeks. On day 15, the birds were assigned to six treatment groups of forty birds each. The control (Con) group was fed a diet without any additive for 3 weeks. The diet of group sulforaphane (SFN) contained broccoli extract providing $0.075 \mathrm{~g} / \mathrm{kg}$ SFN, whereas the diets of the other four groups contained $0 \cdot 15 \mathrm{~g} / \mathrm{kg}$ essential oils from turmeric (Cuo), oregano (Oo), thyme and rosemary (Ro). Weight gain and feed conversion were slightly impaired by Cuo and Oo. In the jejunum SFN, Cuo and Ro increased the expression of xenobiotic enzymes (epoxide hydrolases 1 and 2 and aflatoxin B1 aldehyde reductase) and of the antioxidant enzyme haeme oxygenase regulated by an 'antioxidant response element' (ARE) compared to group Con. In contrast to our expectations in the liver, the expression of these enzymes was decreased by all the additives. Nevertheless, all the additives increased the Trolox equivalent antioxidant capacity of the jejunum and the liver and reduced Fe-induced lipid peroxidation in the liver. We conclude that the up-regulation of $A R E$ genes in the small intestine reduces oxidative stress in the organism and represents a novel mechanism by which phytogenic feed additives improve the health of farm animals.
\end{abstract}

\section{Key words: Chickens: Phytogenic feed additives: Broccoli extract: Essential oils: Xenobiotic enzymes: Antioxidant system}

Since the ban on antibiotic feed additives in the European Union (EU) in 2006, research in alternative substances has gained in importance. In particular for growing broilers and for weaned pigs, several feed additives have been investigated with regard to the prevention of diarrhoea and to increasing general performance and health. Besides pre- and/or probiotics and organic acids, phytogenic substances are most commonly used for this purpose. Phytogenic feed additives comprise a heterogenous group of plant-derived products including herbs, spices, essential oils or other preparations. In particular, labiatae plant oils from Origanum vulgare, Thymus vulgaris and Rosmarinus officinalis have been reported to promote the performance and health of poultry via three different mechanisms ${ }^{(1)}$.

The first mechanism suggests that essential oils (EO) positively affect the growth and performance of chickens by improving feed palatability, secretion of digestive enzymes and nutrient digestibility. Data regarding this topic are, however, not consistent ${ }^{(2-5)}$.

The second mechanism suggests that the EO of labiatae plants exert antibiotic-like bactericidal and/or bacteriostatic effects on several pathogenic intestinal micro-organisms. Most of the studies in this context have been carried out in vitro, frequently in the context of food safety of meat products. For instance, carvacrol, the main monoterpene compound in oregano- and thymbra spicata oil, exhibited a distinct bactericidal activity against Escherichia coli, including an enterohaemorrhagic $\operatorname{strain}^{(6,7)}$, Salmonella enterica ${ }^{(8)}$, Staphylococcus epidermis and $S$. aureus, and numerous other bacteria ${ }^{(9)}$. However, the limitation of the bactericidal effects of EO was demonstrated in an experiment with Caco- 2 cells. The addition of oregano oil (Oo) and thyme oil (To) to the culture media in a concentration $(0.05 \%)$ that strongly inhibited the growth of enteroinvasive $E$. coli also

\footnotetext{
Abbreviations: ABCC2, ATP-binding cassette subfamily C member 2; AFAR, aflatoxin B1 aldehyde reductase; ARE, antioxidant response element; ARP1, acid ribosomal protein 1; Con, control; Cu/Zn SOD, cytosolic Cu/Zn superoxide dismutase; Cuo, turmeric oil; CYP1A1, cytochrome P450 family 1 subfamily A polypeptide 1; ELFA, elongation factor 1 $\alpha$; EO, essential oils; EPHX1, microsomal epoxide hydrolase; EPHX2, cytosolic epoxide hydrolase; EU, European Union; GAPDH, glycerine aldehyde-3-phosphate dehydrogenase; GPx, glutathione peroxidase; GPx1, cytosolic glutathione peroxidase; GPx2, gastrointestinal glutathione peroxidase; GST, glutathione-S-transferases; HMOX, haeme oxygenases; Keap1, Kelch-like erythroid CNC homologueassociated protein 1; Mn SOD, mitochondrial Mn superoxide dismutase; Nrf2, nuclear factor erythroid 2-related factor 2; Oo, oregano oil; Ro, rosemary oil; SFN, sulforaphane; SOD, superoxide dismutase; TBARS, thiobarbituric acid-reactive substances; TEAC, Trolox equivalent antioxidant capacity; To, thyme oil; TrxR, thioredoxin reductase.
}

*Corresponding author: Professor A. S. Mueller, fax + 49345 5527124, email andreas.mueller@landw.uni-halle.de 
was harmful to the cells, whereas lower EO concentrations (0.01\%), causing no cell damage, exhibited a drastically reduced bactericidal activity ${ }^{(10)}$. However, the in vivo bactericidal activity of the EO from labiatae plants in vivo is in doubt. Whereas two trials with growing broilers reported that even low dietary concentrations of carvacrol $(100 \mathrm{mg} / \mathrm{kg})^{(11)}$ and thymol $(15 \mathrm{mg} / \mathrm{kg})^{(12)}$ had a bactericidal activity against $E$. coli and Clostridiae, or influenced the growth of Lactobacillae positively ${ }^{(11-13)}$, in another study an even higher concentration of Oo $(1000 \mathrm{mg} / \mathrm{kg})$ failed to influence bacterial counts in faeces and in caecal chymus ${ }^{(4)}$.

The third mechanism suggests that the EO of labiatae plants positively affect animal health by direct antioxidant effects based on the high availability of the phenolic terpenes carvacrol and thymol. The TROLOX ${ }^{\circledR}$ equivalent, also referred to as Trolox equivalent antioxidant capacity (TEAC), is a common method to study the antioxidant potential of antioxidant compounds in comparison to the water-soluble vitamin $\mathrm{E}$ derivative TROLOX ${ }^{\circledR}$ as the reference substance. In vitro testing of the TEAC value $\left(\mathrm{mmol}\right.$ TROLOX $\left.{ }^{\circledR} / \mathrm{g} \mathrm{DM}\right)$ of ethanolic extracts of twenty-six spices showed that oregano had the highest antioxidant potential within labiatae plants (TEAC value: 100.7), followed by rosemary $(38 \cdot 8)$ and thyme $(38 \cdot 1)^{(14)}$.

Beside the EO of labiatae plants, similar mechanisms improving the performance and health of farm animals have been reported for Zingiberaceae plant extracts, particularly for turmeric (Curcuma longa L.). Comparable to labiatae oils, turmeric oil (Cuo) contains a highly active terpene, the sesquiterpene ar-turmerone. Ar-turmerone has been demonstrated to evolve a strong bactericidal activity against several microorganisms $^{(15)}$. The limited direct antioxidant activity of Cuo (TEAC value: approximately $25 \cdot 5)^{(16)}$ compared to labiatae oils derives from the fact that ar-turmerone is not a phenolic terpene.

Broccoli extract, containing the isothiocyanate sulforaphane (SFN) in the form of its glucosinolate precursor glucoraphanin, is a phytogenic substance that has not yet been studied as a feed additive, and it is not yet permitted in the EU. In human nutrition, broccoli extract and SFN are generally accepted dietary supplements exerting a high anti-carcinogenic potential, in particular against intestinal cancers ${ }^{(17)}$. The safety of broccoli extract has been proven for humans ${ }^{(18)}$. Promising results for SFN have also been published with regard to a strong bactericidal activity against various pathogenic intestinal micro-organisms ${ }^{(19)}$. The anti-carcinogenic effects of turmeric and of SFN are based on the induction of genes with an 'antioxidant response element' (ARE) in their DNA promoter. ARE containing genes include xenobiotic- and antioxidant enzymes such as glutathione- $S$-transferases (GST), epoxide hydrolases, aflatoxin B1 aldehyde reductases (AFAR), haeme oxygenases (HMOX), thioredoxin reductase (TrxR) and cytosolic $\mathrm{Cu} / \mathrm{Zn}$ superoxide dismutase $(\mathrm{Cu} / \mathrm{Zn} \mathrm{SOD}) 1^{(20-26)}$.

$A R E$ gene induction depends on the transcription factor 'nuclear factor erythroid 2-related factor 2' (Nrf2). When the cells are protected sufficiently against oxidative stress, Nrf2 is associated with the Kelch-like erythroid CNC (cap-'n'collar) homologue-associated protein 1 (Keap1) in the cytosol. Oxidative stress or electrophiles like SFN or terpenes modify Keap1 at redox-sensitive $-\mathrm{SH}$-groups ${ }^{(27)}$, leading to
Nrf2 liberation and its nuclear translocation. Subsequently, $\mathrm{Nrf} 2$ binds to the ARE promoter sequence of the aforementioned xenobiotic- and antioxidant enzymes and initiates the up-regulation of their gene expression ${ }^{(28)}$.

In contrast to a number of studies that have investigated the beneficial effects of phytogenic feed additives via the mechanisms (1) - (3), their indirect antioxidant potential via the induction of xenobiotic- and antioxidant enzymes has not been studied in farm animals till now. To the best of our knowledge, only one trial has reported on the induction of xenobiotic enzymes by thyme in mouse liver ${ }^{(29)}$.

Consequently, we aimed to study the induction of AREregulated xenobiotic- and antioxidant enzymes by various EO from labiatae plants in the intestine and the liver of fastgrowing broiler chickens. We used broccoli sprouts extract and Cuo as reference substances, both having a proven impact on $A R E$ gene expression. Moreover, we studied the effects of broccoli extract, not yet permitted as a feed additive in the $\mathrm{EU}$, on performance parameters.

\section{Methods and materials}

\section{Bird husbandry and diets}

The protocol of the broiler study was approved by the Regional Council of Halle and by the Animal Welfare Committee of the Martin Luther University Halle-Wittenberg (record token: 45.202-3-559 MLU). Further, a certificate of exemption for feeding the broccoli sprouts extract, not yet permitted to be used as a feed additive in the EU, was attested by the veterinary administrative office, Saxony Anhalt, Halle (record token: $203.2 .1 / 22 \cdot 10$ )

A total of 240 male Ross-308 broiler chickens ( $1 \mathrm{~d}$ old) (mean body weight: 41.9 (SE 0.57 ) g) were obtained from a hatchery (Geflügelhof Möckern ZN (Zucht and Nutzvieh) der Lohmann \& Co. AG, Möckern, Germany) and fed a commercial starter diet (Landkornstarter, DEUKA, Könnern, Germany) without phytogenic feed additives for $14 \mathrm{~d}$. On day 15 , the birds were assigned to the six experimental groups of forty birds each, with a mean live weight of 442 (SE 14.7) g. Broilers were kept in a stainless-steel cage battery in groups of eight birds per cage and fed the experimental diets for $21 \mathrm{~d}$. The experimental design included five cages of eight birds per diet. The broilers had free access to their diets and water. During the experiment, temperature, humidity and lighting were controlled. The temperature was gradually reduced from $34^{\circ} \mathrm{C}$ on day 1 to $19^{\circ} \mathrm{C}$ on day 35 . The lighting regime consisted of a $12 \mathrm{~h}$ light $-4 \mathrm{~h}$ dark$4 \mathrm{~h}$ light $-4 \mathrm{~h}$ dark cycle. The light intensity of 20 lux and all other housing conditions were in accordance with the recommendations for poultry of the Society for Laboratory Animal Science ${ }^{(30)}$. During the $21 \mathrm{~d}$ experimental period, the control (Con) group was fed a diet, meeting the nutritional requirements of growing broilers, without a phytogenic additive. Minerals, vitamins and essential amino acids were added to all diets as recommended for broilers by the Society of Nutrition Physiology ${ }^{(31)}$ and the National Research Council ${ }^{(32)}$. The diet of group SFN contained $3000 \mathrm{mg} / \mathrm{kg}$ broccoli sprouts extract providing $75.0 \mathrm{mg} / \mathrm{kg} \mathrm{SFN}$, whereas $150.0 \mathrm{mg} / \mathrm{kg}$ of the 
essential oils from C. longa (Cuo), T. vulgaris (To), O. vulgare (Oo) and rosemary oil ( $R$. officinalis, Ro) were added to the diets of the other four experimental groups The active ingredients in the broccoli sprouts extract and the EO, as provided by the manufacturers, had the following concentrations ( $\mathrm{g} / 100 \mathrm{~g}=\%$ ): broccoli sprouts extract (SFN, 5.00), Cuo (arturmerone, 30.0), Oo (carvacrol, 65.0), To (thymol, 49.0) and Ro (1,8-cineole, 46.0). Premixes of all phytogenic feed additives were prepared in $20 \mathrm{~g}$ wheat bran and $10 \mathrm{~g}$ sunflower oil and added to $970 \mathrm{~g}$ of the basal diet (Table 1). All diets were pelleted with a pellet mill using a $3 \mathrm{~mm}$ dye. Feed intake and individual live weight were recorded once a week. Feed conversion was calculated from the ratio of feed intake $(\mathrm{g})$ and weight gain (g). On day 35, the broilers were killed after stunning for organ sampling (liver, small-intestine mucosa and colon). Small-intestine mucosa samples were taken from a $15 \mathrm{~cm}$ jejunal segment located $10 \mathrm{~cm}$ distal to the duodenum. Colon tissue was taken from a $10 \mathrm{~cm}$ segment located distal to the caecum.

\section{RNA preparation and real-time RT-PCR assay including stability analysis of four selected reference genes in the jejunal mucosa, colon and liver}

Relative mRNA expression levels were measured for GST $\alpha$, HMOX1, TrxR1, microsomal epoxide hydrolase 1 (EPHX1), cytosolic epoxide hydrolase 2 (EPHX2), AFAR, cytochrome P450, family 1, subfamily A, polypeptide 1 (CYP1A1) and ATP-binding cassette, sub-family C (cystic fibrosis transmembrane conductance regulator multidrug resistance-associated

Table 1. Composition of the basal diet*

\begin{tabular}{lc}
\hline Ingredient & Basal diet $(\mathrm{g} / \mathrm{kg})$ \\
\hline Wheat (DEUKA GmbH und & 500.0 \\
$\quad$ Company KG, Könnern, Germany) & 165.5 \\
Maize (DEUKA GmbH und Company KG) & 250.0 \\
Soyabean meal, 44\% CP & \\
$\quad$ (DEUKA GmbH und Company KG) & 40.0 \\
Soyabean oil & 10.0 \\
Calcium phosphate (Sigma-Aldrich, & \\
$\quad$ Taufkirchen, Germany) & 15.0 \\
Calcium carbonate (Sigma-Aldrich) & 3.00 \\
NaCl (Sigma-Aldrich) & 8.00 \\
Vitamin and mineral premix $†$ & 4.00 \\
Lysine hydrochloride (Sigma-Aldrich) & 3.00 \\
DL-Methionine (Degussa, Duesseldorf, Germany) & 1.50 \\
L-Threonine (Sigma-Aldrich) & 1000 \\
Total & 12.73 \\
AME & \\
\hline
\end{tabular}

AME, apparent metabolisable energy; $\mathrm{CP}$, crude protein

* The complete diets had the following nutrient contents according to the National Research Council recommendations for poultry ${ }^{(32)}$ and did not differ between the diets: DM (analysed), $91 \%$; gross energy (analysed), $17.25 \mathrm{MJ} / \mathrm{kg} ; \mathrm{AME}_{\mathrm{N} \text {-corrected }}$

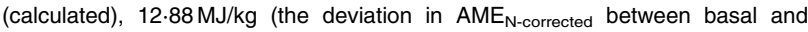
complete diet resulted from adding the different phytogenic feed additives in terms of premixes as described in Methods and materials); crude fat (analysed), $66.4 \mathrm{~g} / \mathrm{kg} \mathrm{DM}$; CP (analysed), $201 \mathrm{~g} / \mathrm{kg} \mathrm{DM;} \mathrm{fibre} \mathrm{(analysed),} 41.0 \mathrm{~g} / \mathrm{kg} \mathrm{DM;} \mathrm{crude}$ ash (analysed), $59 \cdot 8 \mathrm{~g} / \mathrm{kg} \mathrm{DM}$.

†Premix supplied the following according to the supplier (BASU-Mineralfutter $\mathrm{GmbH}$, Bad Sulza, Germany; per kg of complete diet): Ca, $2.3 \mathrm{~g}$; vitamin A, $3.6 \mathrm{~g}$ (as retinyl acetate); cholecalciferol, $0.008 \mathrm{mg}$; vitamin $\mathrm{E}, 38.22 \mathrm{~g}$ (as DL- $\alpha$ tocopheryl acetate); vitamin $\mathrm{K}_{3}, 2 \mathrm{mg}$; thiamine, $2 \mathrm{mg}$; riboflavin, $6.6 \mathrm{mg}$; vitamin $\mathrm{B}_{6}, 5 \mathrm{mg}$; vitamin $\mathrm{B}_{12}, 0.02 \mathrm{mg}$; niacin, $99 \mathrm{mg}$; folic acid, $1 \mathrm{mg}$; biotin, $0.15 \mathrm{mg}$ Ca-D-panthothenate, $15 \mathrm{mg}$; choline chloride, $0.7 \mathrm{~g} ; \mathrm{Cu}, 5 \mathrm{mg} ; \mathrm{Zn}, 51 \mathrm{mg} ; \mathrm{Fe}$, $60 \mathrm{mg}$; Mn, $71 \mathrm{mg}$; I, 0.6 mg; Se, $0.2 \mathrm{mg}$. protein; CFTR/MRP), member 2 (ABCC2). Therefore, total RNA was isolated from the liver, jejunal mucosa and colon of four birds per repetition and the experimental group ( $n$ 120, half the number of experimental birds) using Trizol@ reagent (Invitrogen GmbH, Darmstadt, Germany), according to the manufacturer's protocol. RNA concentration and purity were evaluated photometrically at 260 and $280 \mathrm{~nm}$. Additionally, RNA quality was controlled by checking the integrity of the 18S- and 28S-ribosomal RNA bands and by controlling the absence of genomic DNA. In brief: following the denaturation of $4.5 \mu \mathrm{l}$ of diluted RNA $(05 \mu \mathrm{g} / \mu \mathrm{l})$ with $2.0 \mu \mathrm{l} 5 \times$ gel running buffer, $3.5 \mu \mathrm{l}$ formaldehyde and $10 \mu \mathrm{l}$ formamide at $70^{\circ} \mathrm{C}$ for $10 \mathrm{~min}$, the samples were chilled on ice. Then, $1.0 \mu \mathrm{l}$ of a ethidium bromide solution $(1.0 \mu \mathrm{g} / \mu \mathrm{l})$ and $2.0 \mu \mathrm{l}$ of sample loading buffer were added and the samples were run in $1.2 \%$ agarose gels, containing $2 \cdot 2 \mathrm{M}$-formaldehyde and visualised under a UV-imager (Syngene, Cambridge, UK). Subsequently, $1.5 \mu \mathrm{g}$ of the RNA of two birds per treatment were pooled and subjected to reverse transcription using a commercial complementary DNA synthesis kit (RevertAid ${ }^{\mathrm{TM}}$ First Strand synthesis kit; Fermentas GmbH, St Leon-Rot, Germany). In this manner, $n 10$ complementary DNA pools per treatment were generated and could be subjected to mRNA expression analysis by realtime detection PCR (RT-PCR) using a Rotorgene 6000 apparatus (Corbett Research/QIAGEN GmbH, Hilden, Germany). The complementary DNA obtained by reverse transcription $(20 \mu \mathrm{l})$ was diluted 2.5-fold (final volume $50 \mu \mathrm{l}$ ) with diethylpyrocarbonatetreated sterile water. The standard PCR protocol consisted of an initial denaturation step $\left(95^{\circ} \mathrm{C}, 3 \mathrm{~min}\right)$, followed by $25-32$ amplification cycles (denaturation: $95^{\circ} \mathrm{C}, 25 \mathrm{~s}$, annealing: $60^{\circ} \mathrm{C}, 30 \mathrm{~s}$, and elongation: $72^{\circ} \mathrm{C}, 55 \mathrm{~s}$ ). Subsequent to the identification of the correct length of the amplification products in $1.2 \%$ agarose gels, relative quantification of mRNA expression was performed using the $\Delta \Delta C_{\mathrm{t}} \operatorname{method}^{(33)}$. In accordance with the current guidelines for the proper determination of gene expression data in various tissues (MIQE guidelines) ${ }^{(34)}$, a set of four reference genes was selected and their expression stability $(M)$ was ranked according to the standard procedure ${ }^{(35)}$. Acid ribosomal protein 1 (ARP1), glycerine aldehyde-3-phosphate dehydrogenase (GAPDH), elongation factor $1 \alpha$ (ELFA) and $\beta$-actin were selected as capable reference genes reported in current literature ${ }^{(36,37)}$, and their expression ( $C_{\mathrm{t}}$ values) was measured in the jejunum, the colon and the liver. The treatment independent expression stability $(M)$ was determined by calculating the $C_{\mathrm{t}}$ ratios of one gene with all the other genes. Subsequently, the standard deviation of the logarithmically transformed ratios was calculated and plotted ${ }^{(35)}$. According to their expression stability $M$, indicated by a decrease of standard deviation, a ranking of the most stable reference genes was compiled for each tissue investigated. The best set of housekeeping genes was used for normalisation of the expression data of the target genes. The expression values of the target genes were normalised using the arithmetic mean of the $C_{\mathrm{t}}$ values of ARP1 and $\beta$-actin in the jejunal mucosa, of GAPDH and ELFA in the colon, and of GAPDH and $\beta$-actin in the liver.

The primers used in PCR and their gene bank accession numbers were as follows: 
ARP1 (X13876.1), primer forward $\left(5^{\prime} \rightarrow 3^{\prime}\right)$ : ATC GAC ATC GGA AGC CTC AT, primer reverse $\left(5^{\prime} \rightarrow 3^{\prime}\right)$ : GAC CAA AGC CCA TGT CAT CA; GAPDH (NM204305.1), primer forward $\left(5^{\prime} \rightarrow 3^{\prime}\right)$ : CCT CTC TGG CAA AGT CCA AG, primer reverse $\left(5^{\prime} \rightarrow 3^{\prime}\right)$ : TCT CCA TGG TGG TGA AGA CA; ELFA (L00677.1), primer forward $\left(5^{\prime} \rightarrow 3^{\prime}\right)$ : ACC TCT GCG TCT GCC TCT TC, primer reverse $\left(5^{\prime} \rightarrow 3^{\prime}\right)$ : TTC GCT AAG GGC TTC ATG GT; $\beta$-actin (LO8165), primer forward $\left(5^{\prime} \rightarrow 3^{\prime}\right)$ : ATG AAG CCC AGA GCA AAA GA, primer reverse $\left(5^{\prime} \rightarrow 3^{\prime}\right)$ : GGG GTG TTG AAG GTC TCA AA; GST $\alpha$ (NM001001777), primer forward $\left(5^{\prime} \rightarrow 3^{\prime}\right)$ : TTC TCT CCA CCT GAG GCA AAG, primer reverse $\left(5^{\prime} \rightarrow 3^{\prime}\right)$ : GGC TTC CAT GAG CTG AAC ATC; HMOX1 (NM205344), primer forward $\left(5^{\prime} \rightarrow 3^{\prime}\right)$ : CTG GAG AAG GGT TGG CTT TCT, primer reverse $\left(5^{\prime} \rightarrow 3^{\prime}\right)$ : GAA GCT CTG CCT TTG GCT GTA; TrxR1 (NM001030762), primer forward $\left(5^{\prime} \rightarrow 3^{\prime}\right)$ : AGT CAT TTC TGG CCA CTG GAA, primer reverse $\left(5^{\prime} \rightarrow 3^{\prime}\right)$ : TTGGTGATGGACAGAGTGGTG; EPHX1 (XM419497), primer forward $\left(5^{\prime} \rightarrow 3^{\prime}\right)$ : CAA GTG ATG CTT GGG GCT TAC, primer reverse $\left(5^{\prime} \rightarrow 3^{\prime}\right)$ : ACC TGC AGT GTC TGG TTT GGT; EPHX2 (NM001033645), primer forward $\left(5^{\prime} \rightarrow 3^{\prime}\right)$ : GAA AGC CCT TAT CCG TTC CAC, primer reverse $\left(5^{\prime} \rightarrow 3^{\prime}\right)$ : GGT CTC ATG TTC CGG TAC CAA; AFAR (XM417628.2), primer forward $\left(5^{\prime} \rightarrow 3^{\prime}\right)$ : CAA ACT GCA GGG TTC TCT TGG, primer reverse $\left(5^{\prime} \rightarrow 3^{\prime}\right)$ : GAA GTA GTT GGG GCA GTC GTG; CYP1A1 (NM205146), primer forward $\left(5^{\prime} \rightarrow 3^{\prime}\right)$ : GAAGATTCAGGCAGAGCTGGA, primer reverse $\left(5^{\prime} \rightarrow 3^{\prime}\right)$ : AGT AGC CAT TCA GCA CCG TGT; ABCC2 (XM421698), primer forward $\left(5^{\prime} \rightarrow 3^{\prime}\right)$ : CCG CAG CAT CAG TAC ACA GAG, primer reverse $\left(5^{\prime} \rightarrow 3^{\prime}\right):$ GAA GGA AAA GCC CAA ACC AAC.

\section{Differential superoxide dismutase activity in the liver}

The differential measurement of SOD activity (total SOD, mitochondrial Mn SOD (Mn SOD) and $\mathrm{Cu} / \mathrm{Zn}$ SOD) in the jejunum and the liver was assayed using a photometric standard procedure in which the inhibition of pyrogallol (1,2,3-trihydroxybenzol) autoxidation by the SOD activity of the samples is recorded ${ }^{(38)}$. Following this, 1:5 (w/v) crude homogenates of the liver were prepared in $0 \cdot 1 \mathrm{~m}$-potassium phosphate buffer $(\mathrm{pH} 6.5)$. The formation of purpurogallin by pyrogallol oxidation was measured for $3 \mathrm{~min}$ at $420 \mathrm{~nm}$. Each determination included a blank without the liver homogenate. Here, one unit of SOD activity was defined as the $50 \%$ inhibition of pyrogallol autoxidation to purpurogallin by the samples' SOD activity. The determination of Mn SOD was carried out as previously mentioned, in $50 \mathrm{~mm}$-Tris succinate buffer, containing additionally 100 mm-potassium cyanide to inhibit $\mathrm{Cu} / \mathrm{Zn}$ SOD. Activity of $\mathrm{Cu} / \mathrm{Zn}$ SOD was calculated from the difference of total SOD and Mn SOD activity. Data were normalised to $1 \mathrm{mg}$ of protein. Organ sample pools were generated in an analogous manner as described for mRNA expression. The SOD activity of each sample pool ( $n$ 10) was measured in duplicate.

\section{Glutathione peroxidase 1 activity in the liver and} combined activity of glutathione peroxidases 1 and 2 in the jejunum

The activity of liver cytosolic glutathione peroxidase (GPx1) and the combined activity of GPx1 and gastrointestinal glutathione peroxidase (GPx2) in the jejunal cytosolic supernatant were measured spectrophotometrically (Ultrospec 3300 pro; Amersham Pharmacia Biotech, Freiburg, Germany) at $340 \mathrm{~nm}$ using the assay protocol coupled to glutathione reductase and $\mathrm{NADPH}^{(39)}$. NADPH oxidation, which is proportional to glutathione peroxidase (GPx)-dependent peroxide reduction, was recorded for $3 \mathrm{~min}$. For both enzymes, $\mathrm{H}_{2} \mathrm{O}_{2}$ was used as substrate. Here, one unit of GPx1 and of combined GPx1- and GPx2 activity was defined as $1 \mu \mathrm{mol}$ NADPH oxidised per min and normalised to $1 \mathrm{mg}$ protein. Organ sample pools were generated in an analogous manner as described for mRNA expression. GPx activity of each sample pool ( $n$ 10) was measured in duplicate.

Trolox equivalent antioxidant capacity $=$ TROLOX ${ }^{\circledR}$ equivalent in the essential oils, the jejunal mucosa and the liver

TEAC in 1:5 (w/v) crude homogenates of the liver and of the jejunal mucosa as well as of the essential oils used in the study was measured using the method originally described by Miller et al. ${ }^{(40)}$ with modifications of Wang et al. ${ }^{(41)}$. The method is based on monitoring the inhibition of 2,2'-azino-bis (3-ethylbenzothiazoline-6-sulphonic acid (ABTS) radical formation spectrophotometrically at $600 \mathrm{~nm}$ and $20^{\circ} \mathrm{C}$ for $15 \mathrm{~min}$. The reaction mixture contained PBS buffer, ABTS reagent $(0.15 \mathrm{~mm})$, $\mathrm{H}_{2} \mathrm{O}_{2}(0 \cdot 1 \mathrm{~mm})$ and metmyoglobin $(2 \cdot 50 \mu \mathrm{m})$. Since TROLOX ${ }^{\circledR}$ inhibitory capacity decreases progressively with time, the sample TEAC values were calculated by comparison to the TEAC values of a TROLOX ${ }^{\circledR}$ standard curve (concentration range: $0-21 \cdot 0 \mu \mathrm{M}$ ). The comparisons were done for the linear range of the reaction. Mean TEAC values for the liver and the jejunal mucosa were calculated as the arithmetic mean of the individual TEAC values measured after 3, 5 and $10 \mathrm{~min}$. Before the determination of the TEAC values of the EO, a dilution with $70 \%(\mathrm{v} / \mathrm{v})$ ethanol was carried out. The TEAC values of the samples were expressed in $\mu$ mol TROLOX ${ }^{\circledR}$ equivalent per $g$ organ fresh matter or mmol TROLOX ${ }^{\circledR}$ equivalent per $100 \mathrm{~g}$ essential oil. Organ samples were pooled in an analogous manner as described for mRNA expression. The TEAC value of each sample pool ( $n$ 10) was measured in duplicate.

\section{2-Thiobarbituric acid-reactive substances in the liver}

2-Thiobarbituric acid-reactive substances (TBARS) were measured in the liver of the broilers as a parameter of lipid peroxidation according to a modified protocol from Wong et al. ${ }^{(42)}$. TBARS concentration was measured in liver samples subsequent to the provocation of lipid peroxidation with $\mathrm{FeSO}_{4}$ in order to test their antioxidant capacity. Then, $25 \mu \mathrm{l}$ of the $1: 5(\mathrm{w} / \mathrm{v})$ liver crude homogenates were mixed with $375 \mu \mathrm{H}_{3} \mathrm{PO}_{4}(0.44 \mathrm{M})$ in sealable glass tubes. After the addition of $25 \mu \mathrm{FeSO}_{4}$ solution $(0.05 \mathrm{M}), 200 \mu \mathrm{l}$ aqua bidest and $125 \mu \mathrm{l} 0.6 \% 2$-thiobarbituric acid, the samples were incubated in a thermo block at $100^{\circ} \mathrm{C}$ for $60 \mathrm{~min}$. Determination of the blank was carried out, using $25 \mu$ l of potassium phosphate buffer $(0.1 \mathrm{~m})$ instead of the liver homogenate. Following the incubation at $100^{\circ} \mathrm{C}$, the samples were chilled on ice and 
$750 \mu \mathrm{l}$ of methanolic $\mathrm{NaOH}(10 \mathrm{ml}$ of $1 \mathrm{M}-\mathrm{NaOH}+90 \mathrm{ml}$ methanol) were added. After thorough vortexing and centrifugation at $4000 \mathrm{~g}$ at $4^{\circ} \mathrm{C}$ for $10 \mathrm{~min}$, the extinction was measured spectrophotometrically at $532 \mathrm{~nm}$. Sample TBARS concentrations were calculated from a calibration curve prepared with 1,1,3,3,-tetraethoxypropane in a concentration range of $0 \cdot 60-1 \cdot 20 \mu \mathrm{m}$. TBARS concentration of each sample pool ( $n$ 10) was measured in duplicate.

\section{Protein concentration of samples}

Protein concentration in the liver cytosol, jejunal mucosa, colonic tissue and in the samples for liver immunoblot analysis of $\mathrm{Nrf} 2$ was determined using the standard method of Bradford ${ }^{(43)}$, adapted to the needs for measurement in a ninety-six-well plate reader.

\section{Immunoblot analysis of nuclear factor erythroid 2-related factor 2 in whole liver cell lysate}

For the analysis of Nrf2 protein expression in whole liver cell lysate 1:10 (w/v), liver homogenates were prepared in a nonreducing radioimmuno precipitation assay (RIPA) lysis buffer (50 mm-Tris-HCl, 150 mm-NaCl, 1 mm-phenylmethylsulphonylfluoride, $1 \mathrm{~mm}$-EDTA, $1 \cdot 0 \%$ sodium desoxycholate, $0 \cdot 1 \%$ SDS and $1 \%$ TritonX-100, $\mathrm{pH} 7 \cdot 4$ ). Then, $60 \mu \mathrm{g}$ of protein were separated according to the standard method ${ }^{(44)}$ under non-reducing conditions on $10 \%$ SDS-polyacrylamide gels $\left(50 \mathrm{~mA}, 4^{\circ} \mathrm{C}\right.$, $2 \mathrm{~h}$ ). Separated proteins were transferred onto a polyvinylidene membrane (PALL Biotrace $0.45 \mu \mathrm{m}^{\mathrm{TM}}$; Pall $\mathrm{GmbH}$, Dreieich, Germany) by semi-dry blotting ( $25 \mathrm{~min}$ at a constant $6 \mathrm{~V}$ (approximately $60 \mathrm{~mA})$ ). After blocking the membranes overnight at $4{ }^{\circ} \mathrm{C}$ in Tris-buffered saline-Tween (TBST) $(20 \mathrm{~mm}$ Tris- $\mathrm{HCl}, 150 \mathrm{~mm}-\mathrm{NaCl}, 0 \cdot 1 \%$ Tween $20, \mathrm{pH} 7 \cdot 6$ ) containing $5 \%$ non-fat dry milk and $0 \cdot 2 \%$ bovine serum albumin, the analysis was continued by a $12 \mathrm{~h}$ incubation with the first antibody, a polyclonal anti-rabbit-Nrf2 antibody (Abcam, ab 31 163), in TBS (1:1000) followed by a $1 \mathrm{~h}$ incubation with the secondary antibody (1:3000) linked to horseradish peroxidase (Goat Anti-Rabbit IgG-h + I). Subsequent to three washes with TBST, the protein bands were detected using an ECL-kit (GE Healthcare Europe GmbH, Freiburg, Germany). Optical density of the $57 \mathrm{kDa}$ band, representing active $\mathrm{Nrf} 2$, and of the $101 \mathrm{kDa}$ band, representing ubiquitinated Nrf2 (http://www.abcam. $\mathrm{com} /$ index.html?pageconfig $=$ reviews\&intAbID=31 163), were evaluated with a Phoretix TotalLab TL100 imager (BioStep GmbH, Jahnsdorf, Germany) after scanning the membranes with the biostep Bio-Imaging Systems F-ChemiBIS 3·2M luminescence reader (Berthold Technologies, Bad Wildbad, Germany). The intensity of the Nrf2 bands was normalised to $\beta$-actin, carried along as the standard. Moreover, the ratio of active Nrf2:ubiquitinated Nrf2 was calculated. Whole liver tissue protein pools $(n$ 10) were generated in an analogous manner as described for mRNA expression. Immunoblot analysis was carried out in duplicate for four selected sample pools.

\section{Statistical analysis}

Data are presented as means with their standard errors (except for Table 6 and related remarks). Following assurance of the normality of distribution (Shapiro-Wilk test and
Kolmogorov-Smirnov test) and the homogeneity of variances (Levene's test), the data were analysed with SPSS 19.0 (SPSS, Inc., Chicago, IL, USA) for Windows using the one-way ANOVA procedure. If variances were homogenous, significant differences between means $(P<0.05)$ were evaluated with the least significant difference-test; if not, the Games Howell test was used. Box plots for the analysis of reference gene stability were generated with SPSS 19.0 for Windows (SPSS, Inc.). Other figures were prepared with Microsoft Excel (version 2003; Microsoft Corporation, Redmond, WA, USA).

\section{Results}

Performance parameters (feed intake, body weight, weight gain, feed conversion)

All birds showed no clinical abnormalities during the whole experiment, and no broilers were lost. Both in the initial feeding period (days 1-14) on the commercial starter diet and in the experimental period on diets with the phytogenic feed additives, feed intake did not differ between groups (Table 2). Weight gain between groups was not different in the initial feeding period and in the first 2 weeks of the experimental period (Table 4).

However, in week 5 (days 29-35), broilers of the Cuo group showed a significantly reduced weight gain compared to group Con and to all the other experimental groups with phytogenic feed additives (SFN, Oo, To, Ro). The lower weight gain of group Cuo compared to group Con was also apparent when weight gain data for the experimental period (days 15-35) and the whole experiment (days 1-35) were compared. Broilers of the Oo group produced a significantly lower weight gain over the whole experimental period (days 1-35) compared to Con broilers (Tables 3 and 4). Consequently, broilers of groups Cuo and Oo had a reduced feed conversion compared to Con birds (Table 5). Although no statistical significances could be analysed, broilers of the other groups receiving diets with phytogenic feed additives (SFN, To, Ro) also showed an overall somewhat lower performance than Con broilers, as indicated by weight gain and feed conversion.

\section{Selection of reference genes}

Table 6 shows the medians of the $C_{\mathrm{t}}$ values of the four selected reference genes GAPDH, ARP1, ELFA and $\beta$-actin in the jejunal mucosa, the colon and the liver with their individual standard deviations. Calculation of the percentual standard deviation revealed the following results: In the jejunum, the $C_{\mathrm{t}}$ values of $\beta$-actin produced the highest percentual standard deviation from the median $( \pm 7.58 \%)$, whereas that of ARP1 ( $\pm 6.21 \%)$ was the lowest. Jejunal GAPDH $(7 \cdot 47 \%)$ and ELFA $( \pm 7 \cdot 08 \%)$ showed the highest $C_{\mathrm{t}}$ values, with intermediate values for the percentual standard deviation. In the colon, the following percentual standard deviations were calculated: GAPDH $( \pm 5.55 \%)$, ARP1 $( \pm 6.46 \%)$, ELFA $( \pm 4.67 \%)$ and $\beta$-actin $( \pm 6 \cdot 18 \%)$. Data for the liver percentual standard deviation 
Table 2. Feed intake $(\mathrm{g})$ of growing broilers fed diets containing different phytogenic additives for $21 \mathrm{~d}^{*}$ (Mean values with their standard errors)

\begin{tabular}{|c|c|c|c|c|c|c|c|c|c|c|c|c|}
\hline \multirow[b]{3}{*}{ Group } & \multirow{2}{*}{\multicolumn{2}{|c|}{$\begin{array}{l}\text { Initial period } \\
\text { Days } 1-14\end{array}$}} & \multicolumn{10}{|c|}{ Experimental period } \\
\hline & & & \multicolumn{2}{|c|}{ Days $15-21$} & \multicolumn{2}{|c|}{ Days 22-28 } & \multicolumn{2}{|c|}{ Days 29-35 } & \multicolumn{2}{|c|}{ Days $15-35$} & \multicolumn{2}{|c|}{ Days $1-35$} \\
\hline & Mean & SEM & Mean & SEM & Mean & SEM & Mean & SEM & Mean & SEM & Mean & SEM \\
\hline \multicolumn{13}{|c|}{ Feed intake (g) } \\
\hline Con & $36 \cdot 0$ & 1.60 & $107 \cdot 2$ & 0.83 & $149 \cdot 2$ & 0.14 & 191.5 & 3.55 & $149 \cdot 3$ & 1.44 & $104 \cdot 0$ & 1.44 \\
\hline SFN & $36 \cdot 2$ & $2 \cdot 20$ & $106 \cdot 5$ & $2 \cdot 51$ & $147 \cdot 6$ & $1 \cdot 61$ & $194 \cdot 8$ & 1.65 & $150 \cdot 1$ & $1 \cdot 22$ & 104.5 & 1.52 \\
\hline Cuo & $36 \cdot 6$ & 0.34 & $109 \cdot 4$ & 0.84 & $145 \cdot 5$ & 3.79 & $195 \cdot 6$ & 3.81 & $151 \cdot 4$ & 1.36 & $105 \cdot 5$ & $0 \cdot 76$ \\
\hline Oo & 35.4 & 1.46 & $102 \cdot 0$ & $2 \cdot 80$ & 144.6 & 1.71 & 188.9 & 3.48 & $146 \cdot 7$ & 1.78 & $102 \cdot 2$ & 1.55 \\
\hline To & $36 \cdot 5$ & 1.96 & 109.9 & 1.37 & $145 \cdot 0$ & 4.02 & 191.9 & $5 \cdot 73$ & $150 \cdot 8$ & $2 \cdot 77$ & $104 \cdot 1$ & 1.90 \\
\hline Ro & $34 \cdot 6$ & 1.56 & $102 \cdot 5$ & 3.87 & $145 \cdot 2$ & 1.78 & $188 \cdot 3$ & 3.35 & $146 \cdot 8$ & $2 \cdot 24$ & 101.9 & 1.87 \\
\hline
\end{tabular}

Con, control; SFN, sulforaphane; Cuo, turmeric oil; Oo, oregano oil; To, thyme oil; Ro, rosemary oil.

${ }^{*}$ For details of diets and procedures, see the Methods and materials section.

were: $\pm 4 \cdot 70 \%$ for GAPDH, $\pm 10 \cdot 4 \%$ for ARP1, $\pm 6 \cdot 42 \%$ for ARP1 and $\pm 3.61 \%$ for $\beta$-actin.

To select the most stable pair of reference genes, expression

worst performing gene. The most stable pairs of reference genes after successive exclusion were ARP1 and $\beta$-actin in the jejunal mucosa, GAPDH and ELFA in the colon, and GAPDH and $\beta$-actin in the liver (Table 6).

\section{Expression of antioxidant response element-regulated} xenobiotic-and antioxidant enzymes in the jejunum, the colon and the liver

The analysed normalised gene expression pattern of selected ARE-regulated xenobiotic-and antioxidant enzymes depended on the phytogenic feed additive and on the organ investigated. The jejunal expression of all ARE-regulated genes was up-regulated by the reference additives SFN and Cuo compared to group Con (Table 7, jejunum), with significant changes for HMOX1 (average factor: 1.73), EPHX1 (average factor: 2-10) and AFAR (average factor: 2·10). Among the labiatae oils, only Ro effected a significant up-regulation of HMOX1, EPHX1 and TrxR1 compared to group Con, whereas Oo and To produced no significant changes. In the colon, the expression pattern originating from feeding the phytogenic feed additives differed distinctly from the jejunal profile (Table 7, colon). The number of ARE-regulated genes influenced by the reference additives SFN and Cuo was distinctly lower in the colon than in the jejunum. AFAR was the only colonic gene showing a significant up-regulation by SFN addition to the diet (factor: 1.82) compared to the Con group. Cuo solely increased colonic TrxR1 expression by the factor 2.41. Ro influenced the expression of colonic AREregulated genes most powerful, including HMOX1 (factor: 1.98), EPHX1 (factor: 1.32) and TrxR1 (factor: 2.31). Interestingly, Oo and To that remained without a significant influence on the jejunal expression of ARE-regulated genes had the highest impact on colonic TrxR1 expression (average factor: 3.52). In addition, colonic AFAR expression also responded significantly to Oo treatment (factor: 1.96). In contrast to our expectations, both the reference additives SFN and Cuo and the labiatae oils Oo, To and Ro caused a more or less pronounced down-regulation of the mRNA expression of the ARE-regulated enzymes in the liver of the broilers (Table 7 , liver). In particular, Cuo and Ro decreased the mRNA concentrations of the antioxidant enzymes HMOX1 and TrxR1, and that of the epoxide metabolising enzymes EPHX1 and 2 to a level of $40-50 \%$ of that analysed in the Con group (Table 7 ,

Table 3. Body weight ( $\mathrm{g}$ ) of growing broilers fed diets containing different phytogenic additives for $21 \mathrm{~d}^{\star}$ (Mean values with their standard errors)

\begin{tabular}{|c|c|c|c|c|c|c|c|c|c|c|}
\hline \multirow[b]{3}{*}{ Group } & \multirow{2}{*}{\multicolumn{2}{|c|}{$\frac{\text { Initial period }}{\text { Day } 1}$}} & \multicolumn{8}{|c|}{ Experimental period } \\
\hline & & & \multicolumn{2}{|c|}{ Day 14} & \multicolumn{2}{|c|}{ Day 21} & \multicolumn{2}{|c|}{ Day 28} & \multicolumn{2}{|c|}{ Day 35} \\
\hline & Mean & SEM & Mean & SEM & Mean & SEM & Mean & SEM & Mean & SEM \\
\hline \multicolumn{11}{|c|}{ Body weight (g) } \\
\hline Con & $41 \cdot 0$ & 0.57 & 444.9 & $20 \cdot 8$ & 927.5 & $23 \cdot 1$ & $1465 \cdot 2^{\mathrm{a}}$ & $15 \cdot 2$ & $2350.9^{a}$ & $26 \cdot 9$ \\
\hline SFN & $42 \cdot 2$ & 0.67 & 443.2 & $16 \cdot 9$ & $917 \cdot 6$ & 21.9 & $1444 \cdot 4^{\mathrm{a}, \mathrm{b}}$ & $23 \cdot 8$ & $2301 \cdot 4^{a, b}$ & $19 \cdot 7$ \\
\hline Cuo & $41 \cdot 3$ & 0.52 & 437.5 & $9 \cdot 68$ & 913.0 & $17 \cdot 7$ & $1427 \cdot 0^{a, b}$ & 29.6 & $2234 \cdot 3^{b}$ & 37.7 \\
\hline Oo & $41 \cdot 8$ & 0.54 & $441 \cdot 8$ & $15 \cdot 8$ & $905 \cdot 8$ & $20 \cdot 5$ & $1401 \cdot 8^{b}$ & 12.5 & $2248 \cdot 3^{b}$ & $42 \cdot 7$ \\
\hline To & $41 \cdot 8$ & 0.54 & 442.9 & $13 \cdot 0$ & 928.6 & $19 \cdot 4$ & $1446 \cdot 1^{\mathrm{a}}$ & 8.79 & $2307 \cdot 6^{a, b}$ & 27.9 \\
\hline Ro & $43 \cdot 4$ & 0.58 & $440 \cdot 2$ & $12 \cdot 1$ & $907 \cdot 6$ & $21 \cdot 4$ & $1421 \cdot 0^{a, b}$ & $22 \cdot 8$ & $2279 \cdot 6^{a, b}$ & 30.1 \\
\hline
\end{tabular}

Con, control; SFN, sulforaphane; Cuo, turmeric oil; Oo, oregano oil; To, thyme oil; Ro, rosemary oil.

${ }_{a, b}$ Mean values with unlike superscript letters within a column were significantly different in the least significant difference test or the Games Howell test $(P<0.05)$.

* For details of diets and procedures, see the Methods and materials section. 
Table 4. Weight gain (g) of growing broilers fed diets containing different phytogenic additives for $21 \mathrm{~d}^{*}$ (Mean values with their standard errors)

\begin{tabular}{|c|c|c|c|c|c|c|c|c|c|c|c|c|}
\hline \multirow[b]{3}{*}{ Group } & \multirow{2}{*}{\multicolumn{2}{|c|}{$\begin{array}{l}\text { Initial period } \\
\text { Days } 1-14\end{array}$}} & \multicolumn{10}{|c|}{ Experimental period } \\
\hline & & & \multicolumn{2}{|c|}{ Days $15-21$} & \multicolumn{2}{|c|}{ Days 22-28 } & \multicolumn{2}{|c|}{ Days 29-35 } & \multicolumn{2}{|c|}{ Days $15-35$} & \multicolumn{2}{|c|}{ Days 1-35 } \\
\hline & Mean & SEM & Mean & SEM & Mean & SEM & Mean & SEM & Mean & SEM & Mean & SEM \\
\hline \multicolumn{13}{|c|}{ Weight gain $(\mathrm{g} / \mathrm{d})$} \\
\hline Con & $28 \cdot 9$ & 1.31 & 68.9 & 0.60 & $76 \cdot 8$ & 3.60 & $126 \cdot 5^{\mathrm{a}}$ & $2 \cdot 91$ & $90 \cdot 8^{a}$ & 0.80 & $66 \cdot 0^{a}$ & 0.68 \\
\hline SFN & $28 \cdot 6$ & 1.08 & $67 \cdot 8$ & 1.23 & $75 \cdot 3$ & 3.06 & $122 \cdot 4^{\mathrm{a}}$ & 1.63 & $88 \cdot 5^{a, b}$ & 0.39 & $64 \cdot 6^{a, b}$ & 0.51 \\
\hline Cuo & $28 \cdot 3$ & 0.62 & $67 \cdot 9$ & 1.40 & 73.4 & $4 \cdot 30$ & $115 \cdot 3^{b}$ & $3 \cdot 27$ & $85 \cdot 6^{\mathrm{b}}$ & 1.45 & $62 \cdot 6^{\mathrm{b}}$ & 0.95 \\
\hline Oo & $28 \cdot 6$ & 1.00 & $66 \cdot 3$ & 1.36 & $70 \cdot 9$ & 1.46 & $120 \cdot 9^{a}$ & $10 \cdot 1$ & $86 \cdot 0^{\mathrm{b}}$ & $1 \cdot 16$ & $63 \cdot 0^{\mathrm{b}}$ & 1.09 \\
\hline To & $28 \cdot 7$ & 0.82 & $69 \cdot 4$ & 1.63 & 73.9 & 1.97 & $123 \cdot 1^{\mathrm{a}}$ & $2 \cdot 77$ & $88 \cdot 8^{\mathrm{a}, \mathrm{b}}$ & 1.30 & $64 \cdot 7^{\mathrm{a}, \mathrm{b}}$ & 0.71 \\
\hline Ro & $28 \cdot 4$ & 1.74 & $66 \cdot 8$ & 1.51 & $73 \cdot 8$ & 1.69 & $122 \cdot 2^{\mathrm{a}}$ & $3 \cdot 61$ & $87 \cdot 6^{a, b}$ & 0.89 & $63 \cdot 9^{a, b}$ & 0.77 \\
\hline
\end{tabular}

Con, control; SFN, sulforaphane; Cuo, turmeric oil; Oo, oregano oil; To, thyme oil; Ro, rosemary oil.

a,b Mean values with unlike superscript letters within a column were significantly different in the least significant difference test or the Games Howell test $(P<0.05)$.

${ }^{*}$ For details of diets and procedures, see the Methods and materials section.

liver). Cuo additionally reduced GST $\alpha$ expression significantly. In groups SFN, Oo and To, the expression of HMOX1, EPHX1 and EPHX2 was down-regulated by $15-40 \%$ of the Con level, whereas TrxR1 expression was not influenced (Table 7 , liver).

To judge the changes in the whole xenobiotic metabolising system, we have additionally measured the gene expression of the phase I cytochrome P450 enzyme CYP1A1 and that of the phase III ATP-binding-cassette exporter ABCC2, both having a proven function in mycotoxin detoxification (Table 7 , liver). Cuo that caused the strongest down-regulation of all AREregulated enzymes also reduced the expression of CYP1A1 and ABCC 2 most potently. Similarly for the other phytogenic additives (SFN, Oo, To and Ro), their efficacy on CYP1A1 and ABCC2 mRNA reduction corresponded well to their impact on the down-regulation of the xenobiotic- and antioxidant enzymes investigated. This specific result suggests a down-regulation of the complete liver xenobiotic metabolising machinery by the phytogenic feed additives.

\section{Differential jejunal- and liver superoxide dismutase activity}

Total SOD activity comprises the activity of the cytosolic $\mathrm{Cu} / \mathrm{Zn}$ enzyme $(\mathrm{Cu} / \mathrm{Zn} \mathrm{SOD})$ and of the mitochondrial $\mathrm{Mn}$ enzyme (Mn SOD). $\mathrm{Cu} / \mathrm{Zn}$ SOD is an antioxidant enzyme with an ARE sequence in its DNA promoter. Total jejunal SOD activity was increased significantly by all phytogenic additives, whereas it was decreased to a greater or lesser extent in the liver (Table 8), as analogously observed for gene expression of the xenobiotic- and antioxidant enzymes. Accordingly, the raise in jejunal SOD activity was based to a higher percentage on an increased $\mathrm{Cu} / \mathrm{Zn}$ SOD activity than on changes of Mn SOD. The opposite way around, total SOD activity and, in particular, that of $\mathrm{Cu} / \mathrm{Zn}$ SOD activity were reduced by the phytogenic substances in the liver.

\section{Combined cytosolic glutathione peroxidase- and gastrointestinal glutathione peroxidase activity in the jejunum and liver cytosolic glutathione peroxidase activity}

In the intestine, cytosolic GPx activity comprises the activity of GPx1 and that of GPx2, whereas cytosolic GPx activity in all other organs is restricted to GPx1 action. Both GPx1 and GPx2 sensitively respond to oxidative stress with an upregulation. Comparably to $\mathrm{Cu} / \mathrm{Zn} \mathrm{SOD}, \mathrm{GPx} 2$ also has an ARE in its DNA promoter. As probably observed for $\mathrm{Cu} / \mathrm{Zn}$ SOD, all phytogenic feed additives increased GPx activity in the jejunum to a different extent, but in contrast effected a significant reduction of liver GPx activity (Table 8).

Table 5. Feed conversion $(\mathrm{g} / \mathrm{g})$ of growing broilers fed diets containing different phytogenic additives for $21 \mathrm{~d}^{*}$ (Mean values with their standard errors)

\begin{tabular}{|c|c|c|c|c|c|c|c|c|c|c|c|c|}
\hline \multirow[b]{3}{*}{ Group } & \multirow{2}{*}{\multicolumn{2}{|c|}{$\begin{array}{l}\text { Initial period } \\
\text { Days } 1-14\end{array}$}} & \multicolumn{10}{|c|}{ Experimental period } \\
\hline & & & \multicolumn{2}{|c|}{ Days $15-21$} & \multicolumn{2}{|c|}{ Days 22-28 } & \multicolumn{2}{|c|}{ Days 29-35 } & \multicolumn{2}{|c|}{ Days $15-35$} & \multicolumn{2}{|c|}{ Days $1-35$} \\
\hline & Mean & SEM & Mean & SEM & Mean & SEM & Mean & SEM & Mean & SEM & Mean & SEM \\
\hline \multicolumn{13}{|c|}{ Feed conversion ratio $(\mathrm{g} / \mathrm{g})$} \\
\hline Con & 1.26 & 0.01 & 1.56 & 0.01 & 1.96 & 0.04 & $1 \cdot 34^{\mathrm{a}}$ & 0.05 & $1.65^{\mathrm{a}}$ & 0.03 & $1.58^{\mathrm{a}}$ & 0.02 \\
\hline SFN & 1.27 & 0.03 & 1.64 & 0.09 & 2.02 & 0.09 & $1.41^{\mathrm{a}, \mathrm{b}}$ & 0.03 & $1 \cdot 71^{\mathrm{a}, \mathrm{b}}$ & 0.02 & $1.63^{\mathrm{a}}$ & 0.01 \\
\hline Cuo & 1.32 & 0.03 & 1.64 & 0.04 & 2.05 & $0 \cdot 10$ & $1.57^{\mathrm{b}}$ & 0.11 & $1.79^{\mathrm{b}}$ & 0.03 & $1 \cdot 70^{\mathrm{b}}$ & 0.03 \\
\hline Oo & 1.25 & 0.02 & 1.56 & 0.03 & 2.08 & 0.05 & $1.41^{\mathrm{a}, \mathrm{b}}$ & 0.06 & $1.73^{\mathrm{a}, \mathrm{b}}$ & 0.03 & $1.64^{\mathrm{a}, \mathrm{b}}$ & 0.02 \\
\hline To & 1.28 & 0.03 & 1.60 & 0.04 & 2.02 & 0.18 & $1.39^{a, b}$ & 0.03 & $1 \cdot 71^{\mathrm{a}}$ & 0.02 & $1 \cdot 63^{\mathrm{a}, \mathrm{b}}$ & 0.02 \\
\hline Ro & 1.23 & 0.03 & 1.54 & 0.03 & 2.00 & 0.04 & $1.39^{a, b}$ & 0.05 & $1.68^{\mathrm{a}}$ & 0.03 & $1.60^{\mathrm{a}}$ & 0.03 \\
\hline
\end{tabular}

Con, control; SFN, sulforaphane; Cuo, turmeric oil; Oo, oregano oil; To, thyme oil; Ro, rosemary oil.

${ }^{a, b}$ Mean values with unlike superscript letters within a column were significantly different in the least significant difference test or the Games Howell test $(P<0.05)$.

${ }^{*}$ For details of diets and procedures, see the Methods and materials section. 
Table 6. Cycle threshold values of four reference genes in the jejunal mucosa, colon and liver of growing broilers fed diets containing different phytogenic additivest (Medians and standard deviations)

\begin{tabular}{|c|c|c|c|c|c|c|c|c|}
\hline \multirow[b]{2}{*}{ Tissue } & \multicolumn{2}{|c|}{ GAPDH } & \multicolumn{2}{|c|}{ ARP1 } & \multicolumn{2}{|c|}{ ELFA } & \multicolumn{2}{|c|}{$\beta$-Actin } \\
\hline & MW & SD & MW & SD & MW & SD & MW & SD \\
\hline Liver & $16 \cdot 40^{\star}$ & 0.77 & $15 \cdot 42$ & 1.61 & 15.54 & 1.00 & $17 \cdot 02^{*}$ & 0.61 \\
\hline Jejunum & $17.04^{*}$ & 1.27 & $15 \cdot 77^{\star}$ & 0.98 & $16 \cdot 08$ & 1.14 & $14.06^{\star}$ & 1.07 \\
\hline Colon & $13 \cdot 34^{*}$ & 0.74 & $12 \cdot 40$ & 0.80 & $11.39^{*}$ & 0.53 & $10 \cdot 58$ & 0.65 \\
\hline
\end{tabular}

GAPDH, glycerine aldehyde-3-phosphate dehydrogenase; ARP1, acid ribosomal protein 1; ELFA, elongation factor $1 \alpha$.

* Within a line indicates the most stable reference genes for the different tissues. Average expression stability $(M)$ of remaining reference genes was calculated by stepwise exclusion of the least stable pair of reference genes in the jejunal mucosa, colon and liver. Sample pools $(n 60)$ for all groups, corresponding to ten sample pools per dietary treatment were analysed.

†For details of diets and procedures, see the Methods and materials section.

Immunoblot analysis of nuclear factor erythroid 2-related factor 2 regulation in the liver

All phytogenic feed additives decreased protein abundance of active Nrf2 in whole liver homogenate by $20-39 \%$ compared to group Con. In contrast, relative protein concentration of ubiquitinated Nrf2 was 2.20- to $3 \cdot 60$-fold higher in the liver of broilers receiving any phytogenic feed additive compared to Con broilers. As a consequence, in broilers fed phytogenic feed additives, the ratio of active Nrf2:ubiquitinated Nrf2 decreased to $28-40 \%$ of that in Con broilers (Fig. 1(A) and (B)).

\section{Trolox equivalent antioxidant capacity $=T R O L O X^{\circledR}$ equivalent in the essential oils and the liver}

The analysed TEAC values ( $\mathrm{mmol}$ per $100 \mathrm{ml}$ ) of the essential oils were as follows: Cuo: $90 \cdot 7$ (SE 1.81), Oo: 120 (SE 10.1), To: 116 (SE 8.72) and Ro: 156 (SE 21.1) (Fig. 2). A TEAC value for sulforphane or its glucosinolate precursor glucoraphanin could not be analysed since these compounds possess no direct antioxidant effects. Jejunal TEAC ( $\mu$ mol per $g$ of organ) was 3- to 7-fold lower than that in the liver (jejunum: Con 29.4 (se 9.61), SFN 174 (se 36.6), Cuo 343 (se 22.9), Oo 392 (se 31.0), To 446 (se 43.1), Ro 364 (sE 59.8); liver: Con

Table 7. mRNA expression of xenobiotic- and antioxidant enzymes in the jejunal mucosa, colon and liver of growing broilers fed diets containing different phytogenic additives for $21 \mathrm{~d}$ relative to group control (Con) $=1^{*}$

(Mean values with their standard errors of the mRNA abundance relative to group Con $=1.0$ ( $n 10$ pools of two animals per experimental group))

\begin{tabular}{|c|c|c|c|c|c|c|c|c|c|c|c|c|}
\hline \multirow{2}{*}{$\begin{array}{l}\text { Group... } \\
\text { ARE gene }\end{array}$} & \multicolumn{2}{|c|}{ Con } & \multicolumn{2}{|c|}{ SFN } & \multicolumn{2}{|c|}{ Cuo } & \multicolumn{2}{|c|}{ Oo } & \multicolumn{2}{|c|}{ To } & \multicolumn{2}{|c|}{ Ro } \\
\hline & Mean & SEM & Mean & SEM & Mean & SEM & Mean & SEM & Mean & SEM & Mean & SEM \\
\hline \multicolumn{13}{|l|}{ Jejunum } \\
\hline$G S T \alpha$ & $1.00^{\mathrm{a}}$ & 0.26 & $1.55^{\mathrm{a}}$ & 0.35 & $1 \cdot 14^{\mathrm{a}}$ & 0.62 & $1 \cdot 12^{\mathrm{a}}$ & 0.38 & $0.87^{\mathrm{a}}$ & 0.22 & $0.67^{\mathrm{a}}$ & 0.12 \\
\hline HMOX1 & $1.00^{\mathrm{a}}$ & 0.12 & $1.60^{\mathrm{b}}$ & 0.20 & $1 \cdot 86^{\mathrm{b}}$ & 0.44 & $1.06^{a}$ & 0.17 & $1 \cdot 21^{\mathrm{a}, \mathrm{b}}$ & 0.10 & $1.98^{b}$ & 0.50 \\
\hline$E P H X 1$ & $1.00^{\mathrm{a}}$ & 0.17 & $1.90^{\mathrm{b}}$ & 0.30 & $2 \cdot 19^{\mathrm{b}}$ & 0.44 & $1.59^{\mathrm{a}, \mathrm{b}}$ & 0.37 & $1 \cdot 40^{\mathrm{a}, \mathrm{b}}$ & 0.21 & $1 \cdot 80^{\mathrm{b}}$ & 0.30 \\
\hline$E P H X 2$ & $1.00^{\mathrm{a}}$ & 0.19 & $1.54^{\mathrm{a}}$ & 0.23 & $1.46^{\mathrm{a}}$ & 0.29 & $1.37^{\mathrm{a}}$ & 0.38 & $1 \cdot 14^{\mathrm{a}}$ & 0.12 & $1 \cdot 60^{\mathrm{a}}$ & 0.32 \\
\hline$A F A R$ & $1.00^{\mathrm{a}}$ & 0.06 & $1 \cdot 87^{\mathrm{b}, \mathrm{c}}$ & 0.23 & $2 \cdot 26^{\mathrm{b}}$ & 0.37 & $1 \cdot 16^{\mathrm{a}}$ & 0.19 & $1 \cdot 40^{\mathrm{a}, \mathrm{c}}$ & 0.26 & $1 \cdot 37^{\mathrm{a}, \mathrm{c}}$ & 0.22 \\
\hline TrxR1 & $1.00^{\mathrm{a}}$ & 0.12 & $1 \cdot 29^{a}$ & 0.23 & $1.62^{\mathrm{a}, \mathrm{b}}$ & 0.41 & $1.27^{\mathrm{a}}$ & 0.18 & $1.19^{a}$ & 0.13 & $2 \cdot 12^{\mathrm{b}}$ & 0.36 \\
\hline \multicolumn{13}{|l|}{ Colon } \\
\hline$G S T \alpha$ & $1.00^{\mathrm{a}}$ & 0.14 & $0.79^{\mathrm{a}}$ & $0 \cdot 10$ & $0.99^{\mathrm{a}}$ & 0.09 & $1 \cdot 11^{\mathrm{a}}$ & 0.12 & $0.99^{\mathrm{a}}$ & 0.14 & $1 \cdot 10^{\mathrm{a}}$ & 0.17 \\
\hline HMOX1 & $1.00^{\mathrm{a}, \mathrm{b}}$ & 0.23 & $0.87^{\mathrm{a}}$ & 0.15 & $1.38^{\mathrm{a}, \mathrm{b}, \mathrm{c}}$ & 0.25 & $1.59^{\mathrm{b}, \mathrm{c}}$ & 0.44 & $1 \cdot 39^{\mathrm{a}, \mathrm{b}, \mathrm{c}}$ & 0.28 & $1.98^{\mathrm{C}}$ & 0.43 \\
\hline$E P H X 1$ & $1 \cdot 00^{\mathrm{a}}$ & 0.12 & $0.99^{a}$ & 0.10 & $0 \cdot 86^{\mathrm{a}}$ & 0.06 & $0.95^{a}$ & 0.09 & $1.00^{\mathrm{a}}$ & 0.07 & $1.32^{b}$ & 0.10 \\
\hline EPHX2 & $1.00^{\mathrm{a}}$ & 0.12 & $0.84^{a}$ & 0.08 & $0.89^{\mathrm{a}}$ & 0.10 & $0.84^{a}$ & 0.08 & $1.02^{\mathrm{a}}$ & 0.06 & $0.93^{\mathrm{a}}$ & 0.07 \\
\hline$A F A R$ & $1.00^{\mathrm{a}}$ & 0.13 & $1.82^{\mathrm{b}}$ & 0.28 & $0.95^{\mathrm{a}}$ & 0.08 & $1.96^{\mathrm{b}}$ & 0.43 & $0.93^{a}$ & 0.15 & $1 \cdot 32^{\mathrm{a}, \mathrm{b}}$ & 0.29 \\
\hline $\operatorname{Tr} x R 1$ & $1.00^{\mathrm{a}}$ & 0.31 & $1 \cdot 80^{a, b}$ & 0.53 & $2 \cdot 41^{\mathrm{b}, \mathrm{c}}$ & 0.73 & $3.90^{c}$ & 1.13 & $3.15^{\mathrm{b}, \mathrm{c}}$ & $1 \cdot 14$ & $2 \cdot 31^{b, c}$ & 0.60 \\
\hline \multicolumn{13}{|l|}{ Liver } \\
\hline$G S T \alpha$ & $1.00^{\mathrm{a}}$ & 0.12 & $0.98^{a}$ & 0.08 & $0.67^{b}$ & 0.08 & $1 \cdot 10^{\mathrm{a}}$ & 0.07 & $0.96^{a}$ & 0.12 & $0.95^{a}$ & 0.06 \\
\hline HMOX 1 & $1.00^{\mathrm{a}}$ & 0.23 & $0.62^{b, c}$ & 0.05 & $0.47^{b}$ & 0.04 & $0.62^{b, c}$ & 0.07 & $0.74^{\mathrm{a}, \mathrm{c}}$ & 0.07 & $0.62^{b}$ & 0.07 \\
\hline$E P H X 1$ & $1.00^{\mathrm{a}}$ & 0.07 & $0.85^{\mathrm{a}, \mathrm{c}}$ & 0.07 & $0.53^{\mathrm{b}}$ & 0.49 & $0.81^{c}$ & 0.08 & $0.66^{\mathrm{b}, \mathrm{c}}$ & 0.08 & $0.53^{b}$ & 0.07 \\
\hline$E P H X 2$ & $1.00^{\mathrm{a}}$ & 0.14 & $0.59^{\mathrm{b}, \mathrm{c}, \mathrm{d}}$ & 0.06 & $0.39^{b, d}$ & 0.06 & $0.79^{\mathrm{a}, \mathrm{c}}$ & 0.06 & $0.66^{\mathrm{c}, \mathrm{d}}$ & 0.10 & $0.47^{d}$ & 0.06 \\
\hline$A F A R$ & $1.00^{\mathrm{a}}$ & 0.12 & $1.01^{\mathrm{a}}$ & 0.11 & $0.96^{\mathrm{a}}$ & 0.09 & $0.95^{\mathrm{a}}$ & 0.14 & $0.79^{\mathrm{a}}$ & 0.09 & $0.88^{\mathrm{a}}$ & 0.14 \\
\hline TrxR1 & $1.00^{\mathrm{a}}$ & 0.13 & $0.88^{a}$ & 0.09 & $0.49^{\mathrm{b}}$ & 0.04 & $1.02^{a}$ & 0.12 & $0.96^{a}$ & 0.15 & $0.59^{b}$ & 0.07 \\
\hline CYP1A1 & $1.00^{\mathrm{a}}$ & 0.20 & $0.50^{\mathrm{b}}$ & 0.08 & $0.17^{c}$ & 0.04 & $0.56^{\mathrm{b}}$ & 0.08 & $0.45^{\mathrm{b}}$ & 0.13 & $0.48^{\mathrm{b}}$ & 0.09 \\
\hline$A B C C 2$ & $1.00^{\mathrm{a}}$ & 0.09 & $0.75^{\mathrm{a}}$ & 0.15 & $0.49^{\mathrm{b}}$ & 0.16 & $1.02^{a, c}$ & 0.14 & $0.96^{a, c}$ & 0.23 & $0.55^{\mathrm{b}}$ & 0.05 \\
\hline
\end{tabular}

SFN, sulforaphane; Cuo, turmeric oil; Oo, oregano oil; To, thyme oil; Ro, rosemary oil; GST $\alpha$, glutathione-S-transferase $\alpha$ HMOX1, haeme oxygenase 1; EPHX1, microsomal epoxide hydrolase; EPHX2, cytosolic epoxide hydrolase; AFAR, aflatoxin B1 aldehyde reductase; TrxR1, thioredoxin reductase 1; CYP1A1, cytochrome P450 family 1 subfamily A polypeptide 1; ABCC2, ATP-binding cassette subfamily C member 2.

a,b,c,d Mean values with unlike superscript letters within a row indicate significant differences in the least significant difference test or the Games Howell test $(P<0.05)$ The superscript 'a' was assigned to group Con.

${ }^{*}$ For details of diets and procedures, see the Methods and materials section. 
Table 8. Differential superoxide dismutase (SOD) activity and glutathione peroxidase (GPx) activity in the jejunal mucosa and the liver of growing broilers fed diets containing different phytogenic additives for $21 \mathrm{~d}^{*}$

(Mean values with their standard errors, $n 10$ pools of two animals per experimental group)

\begin{tabular}{|c|c|c|c|c|c|c|c|c|c|c|c|c|}
\hline \multirow[b]{2}{*}{ Group } & \multicolumn{2}{|c|}{ Con } & \multicolumn{2}{|c|}{ SFN } & \multicolumn{2}{|c|}{ Cuo } & \multicolumn{2}{|c|}{ Oo } & \multicolumn{2}{|c|}{ To } & \multicolumn{2}{|c|}{ Ro } \\
\hline & Mean & SEM & Mean & SEM & Mean & SEM & Mean & SEM & Mean & SEM & Mean & SEM \\
\hline \multicolumn{13}{|l|}{ Jejunum } \\
\hline Total SOD (U/mg protein) & $4.88^{\mathrm{a}}$ & 0.73 & $6 \cdot 80^{\mathrm{b}}$ & 0.54 & $7 \cdot 28^{\mathrm{b}}$ & 0.84 & $7 \cdot 20^{\mathrm{b}}$ & 0.55 & $7 \cdot 45^{\mathrm{b}}$ & 0.86 & $7 \cdot 42^{\mathrm{b}}$ & 0.63 \\
\hline $\mathrm{Cu} / \mathrm{Zn} \mathrm{SOD}(\mathrm{U} / \mathrm{mg}$ protein) & $3.87^{\mathrm{a}}$ & 0.76 & $5.55^{\mathrm{b}}$ & 0.52 & $6 \cdot 15^{\mathrm{b}}$ & 0.80 & $5.79^{\mathrm{b}}$ & 0.48 & $6 \cdot 19^{b}$ & 0.77 & $6 \cdot 10^{\mathrm{b}}$ & 0.70 \\
\hline Mn SOD (U/mg protein) & $1.00^{\mathrm{a}}$ & 0.07 & $1 \cdot 25^{a, b}$ & 0.03 & $1 \cdot 13^{\mathrm{a}}$ & 0.09 & $1.41^{\mathrm{b}}$ & $0 \cdot 10$ & $1 \cdot 26^{a, b}$ & 0.10 & $1.32^{a, b}$ & 0.14 \\
\hline GPx (mU/mg protein) & $6 \cdot 87^{\mathrm{a}}$ & 0.57 & $7 \cdot 28^{a, b}$ & 0.85 & $9 \cdot 16^{\mathrm{b}}$ & 0.70 & $8.90^{\mathrm{b}}$ & 0.67 & $7 \cdot 62^{a, b}$ & 1.08 & $7 \cdot 62^{a, b}$ & 0.83 \\
\hline \multicolumn{13}{|l|}{ Liver } \\
\hline Total SOD (U/mg protein) & $59 \cdot 6^{a}$ & 1.90 & $52 \cdot 5^{b, c}$ & $2 \cdot 16$ & $57 \cdot 2^{a, b}$ & $2 \cdot 37$ & $51 \cdot 2^{b, c}$ & 1.58 & $56 \cdot 1^{\mathrm{a}, \mathrm{b}, \mathrm{c}}$ & 1.99 & $49 \cdot 8^{\mathrm{c}}$ & 3.82 \\
\hline $\mathrm{Cu} / \mathrm{Zn} \mathrm{SOD}(\mathrm{U} / \mathrm{mg}$ protein) & $47.4^{\mathrm{a}}$ & 1.79 & $41.4^{b, c}$ & $2 \cdot 36$ & $46 \cdot 5^{a, b}$ & $2 \cdot 24$ & $39 \cdot 6^{\mathrm{c}}$ & 1.55 & $45 \cdot 2^{\mathrm{a}, \mathrm{b}, \mathrm{c}}$ & 1.73 & $44 \cdot 4^{\mathrm{b}, \mathrm{c}}$ & 2.93 \\
\hline Mn SOD (U/mg protein) & $12 \cdot 2^{\mathrm{a}}$ & 0.38 & $11 \cdot 2^{\mathrm{a}}$ & 0.84 & $10 \cdot 8^{\mathrm{a}}$ & 0.49 & $11 \cdot 6^{\mathrm{a}}$ & 0.44 & $10 \cdot 8^{a}$ & 0.70 & $9 \cdot 3^{\mathrm{b}}$ & 1.02 \\
\hline $\mathrm{GPx}(\mathrm{mU} / \mathrm{mg}$ protein) & $26 \cdot 2^{\mathrm{a}}$ & 1.47 & $22 \cdot 1^{b, c}$ & 1.03 & $20 \cdot 7^{b, c}$ & 0.69 & $17 \cdot 0^{\mathrm{C}}$ & 1.49 & $20 \cdot 2^{b, c}$ & 1.54 & $20 \cdot 7^{b, c}$ & 1.19 \\
\hline
\end{tabular}

Cu/Zn SOD, cytosolic Cu-Zn SOD; Mn SOD, mitochondrial Mn SOD.

${ }_{a, b, c}$ Mean values with unlike superscript letters within a row were significantly different in the least significant difference test or the Games Howell test $(P<0.05)$.

${ }^{*}$ For details of diets and procedures, see the Methods and materials section.

282 (SE 28.0), SFN 680 (SE 52.2), Cuo 494 (se 34.9), Oo 992 (SE 57·4), To 1129 (SE 87·1), Ro 764 (SE 115)). All phytogenic feed additives raised the jejunal and liver TEAC values significantly compared to group Con. The TEAC values of Oo and To directly reflected the TEAC values analysed in the jejunum and in the liver of the broilers. Cuo which had a distinctly lower TEAC value than the labiatae oils (Oo, To and Ro) had a distinctly higher influence on the jejunal TEAC than on the liver TEAC. Feeding Ro, with the highest analysed TEAC, resulted in a lower liver TEAC than Oo- and To feeding, whereas its influence on the jejunal TEAC was comparable to that of Oo and To. SFN, having no direct antioxidant activity, increased the jejunal and liver TEAC significantly less than the labiatae oils (Oo, To and Ro).

\section{Concentration of thiobarbituric acid-reactive substances in the liver}

All the phytogenic feed additives tested, effected a reduction of Fe-induced lipid peroxidation in the liver of the broilers compared to the Con group (Fig. 3). Cuo feeding thereby had the strongest effect, reducing TBARS by nearly $60 \%$ compared to group Con. To and Ro as well as SFN produced an intermediate protection against the Fe-provoked lipid peroxidation (reduction of about $40 \%$ ), whereas Oo showed the smallest effect in comparison (reduction of about $20 \%$ ).

\section{Discussion}

Performance parameters (feed intake, body weight, weight gain, feed conversion)

As mentioned in the introduction, the effects of phytogenic feed additives, and in particular of labiatae oils on the performance parameters of broilers are subject to a controversial discussion. Whereas one study reported on the beneficial effects of extremely high dietary concentrations of oregano leaves (up to $20 \mathrm{~g} / \mathrm{kg}=20 \mathrm{~kg} /$ tonne) and Oo (up to $1.0 \mathrm{~g} / \mathrm{kg}=1.0 \mathrm{~kg} /$ tonne) on weight gain and feed conversion $^{(2)}$, other studies showed no effects ${ }^{(3)}$ or even opposite effects on these parameters ${ }^{(5)}$. In the last mentioned study, the influence of Oo, To and Ro on the performance of broilers was studied. In this study, Oo and Ro impaired weight gain and feed conversion compared to control broilers, whereas To influenced these parameters positively. Our results are partially in accordance with these results ${ }^{(5)}$. Although we could not confirm an improvement of performance by To addition to the diet, weight gain was reduced to a lesser extent by To compared to Oo and Ro (Table 2). In studies on the effects of turmeric on aflatoxin-metabolising enzymes, the addition of $500 \mathrm{~g} / \mathrm{t}$ turmeric powder to the diets of Cobb $\times$ Cobb broilers reduced body weight gain and feed conversion of these birds compared to the Con ${ }^{(26,45)}$. Our results for Cuo confirm these results (Table 2), with the difference that the Cobb $\times$ Cobb broilers ${ }^{(46)}$ had a somewhat higher weight gain and a better feed conversion than our Ross-308 broilers ${ }^{(45,47)}$. Broccoli extract (SFN), not yet permitted as a feed additive in the EU, in our trial also influenced the performance parameters of the broilers, slightly negative compared to group Con (Table 2). However, this effect reached only a magnitude comparable to that of To. Feasible negative effects of broccoli extract on performance may derive from the goitrogenic potential of isothiocyanates. However, studies with human subjects have proven that even high dietary concentrations of SFN affect thyroid metabolism only negligibly ${ }^{(18,48)}$.

Weight gain and feed conversion are the two most important goals in today's animal nutrition. Frequently both parameters are associated with general animal health. Our present results and the outcome of a number of the aforementioned studies ${ }^{(2,3,46)}$ suggest that phytogenic feed additives do not meet the criteria acting as mere growth promoters. However, in these studies, including our present experiment, the animals were not subjected to a challenge with pathogenic micro-organisms or toxic substances. It can be assumed that the threat of infections and the challenge with feed contaminants increase under practical feeding conditions with a high stocking rate. Experiments in which broilers were infected with Eimeria tenella or fed aflatoxin-containing diets, Oo or 
(A)

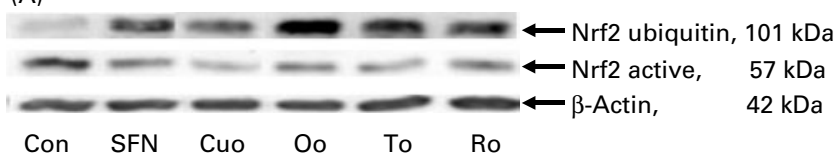

(B)

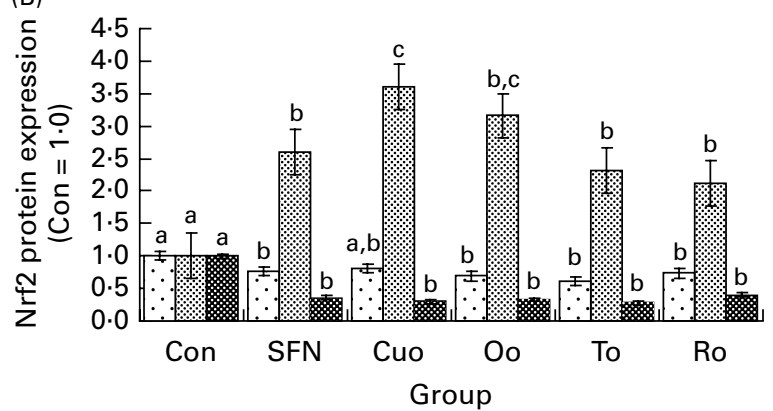

Fig. 1. Nuclear factor erythroid 2-related factor 2 (Nrf2) protein expression in whole liver lysate of growing broilers fed diets containing different phytogenic additives for $21 \mathrm{~d}$. (A) Representative immunoblot of ubiquitinated Nrf2 (=Nrf2 marked with ubiquitin for proteasomal degradation, $101 \mathrm{kDa}$, upper lane), active $\mathrm{Nrf} 2(57 \mathrm{kDa}$, middle lane) and $\beta$-actin ( $42 \mathrm{kDa}$, lower lane), selected from four pools of whole liver tissue homogenate per experimental group. Immunoblot analysis for each protein pool was performed in duplicate. (B) Nrf2 protein expression and ratio of active:ubiquitinated Nrf2 in whole liver lysate of growing broilers fed diets containing different phytogenic additives for $21 \mathrm{~d}$ relative to group Con $=1 \cdot 0$. Values are means, with their standard errors represented by vertical bars of active and ubiquitinated Nrf2 protein abundance relative to group Con $=1.0$ and the ratio of active Nrf2: $\mathrm{u}$ biquitinated Nrf2 relative to group Con $=1.0$ ( $n 4$ pools of two animals per experimental group). ${ }^{a, b, c}$ Mean values with unlike letters were significantly different in the least significant difference test or the Games Howell test $(P<0.05)$. The letter 'a' was assigned to group Con. For details of diets and procedures, see the Methods and materials section. $\square$, Nfr2 active; 圈, Nrf2 ubiquitinated; active:ubiquitinated. Con, control; SFN, sulforaphane; Cuo, turmeric oil; Oo, oregano oil; To, thyme oil; Ro, rosemary oil.

turmeric powder counteracted the depressed feed intake and growth $^{(26,45,49)}$. Moreover, the exclusive addition of phytogenic substances as growth promoters to animal feed may be less effective than combinations with feed enzymes ${ }^{(1,2)}$ or probiotics ${ }^{(50)}$.

Antioxidant response element-regulated xenobiotic- and antioxidant enzymes, Trolox equivalent antioxidant capacity in the intestine

To the best of our knowledge, our data have shown for the first time that labiatae oils have differentiated and promising effects on ARE-regulated xenobiotic- and antioxidant enzymes and on antioxidant capacity in the intestine and the liver of fast-growing broilers. This assertion is also appropriate for Cuo which is permitted as a feed additive in the EU and for broccoli sprouts extract which is currently only accredited as a dietary supplement for humans. Due to their known impact on the induction of ARE-regulated genes, we have applied the aforementioned phytogenic substances as the reference additives in our study. For turmeric and $\mathrm{SFN}^{(51)}$ derived from glucoraphanin cleavage by intestinal microbial $\beta$-glucosidases, our data regarding their impact on the induction of intestinal ARE-regulated xenobiotic- and antioxidant enzymes are in agreement with recent literature. A number of cell culture studies and in vivo studies with human subjects and laboratory animals have demonstrated the potential of turmeric and SFN on the induction of ARE-regulated genes in the intestine ${ }^{(22,52-54)}$. In humans, turmeric and SFN predominantly have been established as preventive agents against intestinal cancers. Their safety has been verified ${ }^{(18,48,55)}$ In farm animals, having a short life span and needed for food production, the application of potent inductors of AREregulated genes rather aims on their efficiency to strengthen the intestinal barrier against toxic feed-derived substances or endogenously produced toxic metabolites and thereby impeding their absorption into the organism. In our trial, Cuo and SFN both induced a similar pattern of ARE-regulated genes in the small intestine (Table 7 , jejunum) with a particular focus on HMOX1, EPHX 1 and 2, and on AFAR ${ }^{(26,45)}$.

Further, our results have shown an effect of labiatae oils (Oo, To, Ro) on the expression of intestinal ARE-regulated genes. The labiatae oils induced a differential expression pattern depending on the oil and on the intestinal segment investigated (Table 7; jejunum, colon). Within the labiatae oils, Oo and To effected a smaller increase in jejunal ARE-regulated enzymes compared to Ro. In the colon, feeding the phytogenic substances resulted in a more individual induction pattern. In the colon, all the additives induced TrxR1 possessing both, antioxidant properties, and a key role in DNA-synthesis ${ }^{(56)}$ to a higher extent than in the jejunum. Whereas SFN and Oo increased the colonic AFAR expression potently, Ro had a high impact on HMOX1 expression. The exact mechanisms by which EO and SFN influence ARE-regulated genes differentially have not been studied to date. It can be speculated that the different main terpene compounds of EO and SFN modify Keap1 at sensor -SH-groups by individual chemical reactions ${ }^{(27)}$. Moreover, the number of ARE and that of other transcription-factor-regulated elements in the promoter region differ between the single xenobiotic- and antioxidant enzymes investigated ${ }^{(57)}$. That terpenes increase

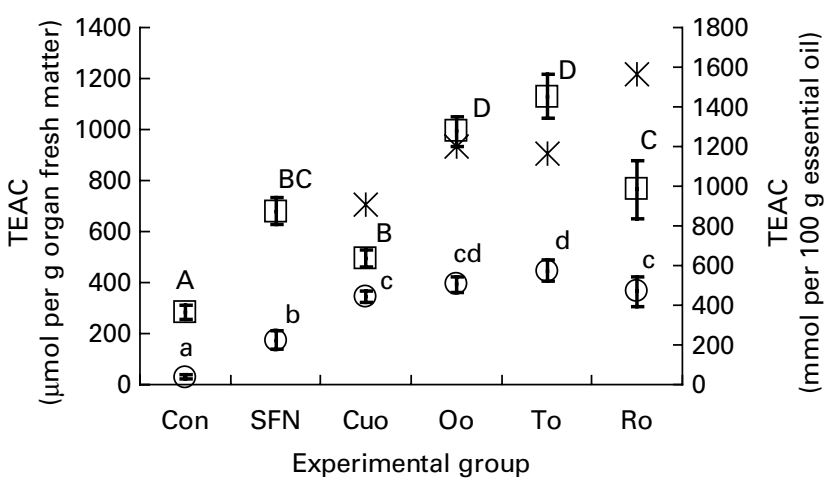

Fig. 2. Trolox equivalent antioxidant capacity (TEAC) values of essential oils ( $*$ ) and TEAC values in jejunal (O) mucosa and the liver ( $\square$ ) of fast-growing broilers fed diets containing different phytogenic additives for $21 \mathrm{~d}$. Values are means, with their standard errors represented by vertical bars ( $n 10$ pools of two animals per experimental group). ${ }^{a, b, c, d}$ Mean values with unlike letters were significantly different in the least significant difference (LSD) test or the Games Howell test for the jejunal TEAC values $(P<0.05)$. ${ }^{A, B, C, D}$ Mean values with unlike letters were significantly different in the LSD test or the Games Howell test for the liver TEAC values $(P<0.05)$. For details of diets and procedures, see the Methods and materials section. Con, control; SFN, sulforaphane; Cuo, turmeric oil; Oo, oregano oil; To, thyme oil; Ro, rosemary oil. 


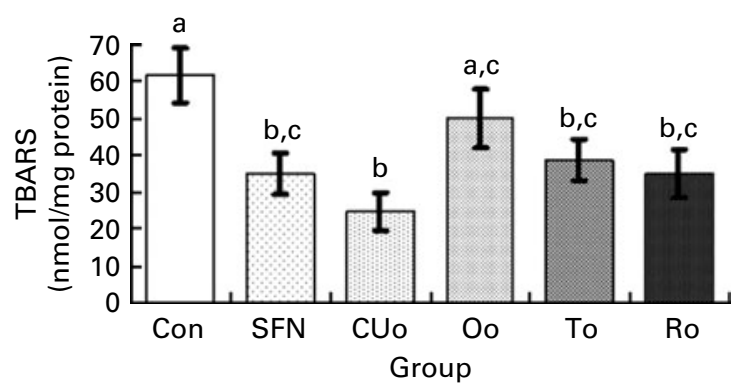

Fig. 3. Thiobarbituric acid-reactive substances (TBARS) after iron provocation in the liver of fast-growing broilers fed diets containing different phytogenic additives for $21 \mathrm{~d}$. Values are means, with their standard errors represented by vertical bars ( $n 10$ pools of two animals per experimental group). ${ }^{a, b, c}$ Mean values with unlike letters were significantly different in the least significant difference test or the Games Howell test $(P<0.05)$. For details of diets and procedures, see the Methods and materials section.

the expression and activity of ARE-regulated enzymes has been demonstrated ${ }^{(23,58,59)}$. In contrast to carvacrol (oregano) and thymol (thyme) ${ }^{(14)}$, the main terpenes of Cuo (ar-turmerone) and of Ro $(1,8 \text { cineole })^{(16,60)}$, accounting for $30-50 \%$ $(\mathrm{v} / \mathrm{v})$ of these oils, have no antioxidant phenolic groups in their molecular structure. For this reason, sesquiterpenes like ar-turmerone (turmeric) or terpenes with an epoxide function like 1,8 cineole (rosemary) may induce ARE-regulated genes more powerful than phenolic monoterpenes ${ }^{(23)}$. On the other hand, the phenolic monoterpenes exert a higher direct antioxidant potential ${ }^{(16)}$. In this context, our results for the TEAC values of the oils and of jejunal mucosa are of interest (Fig. 2). The TEAC value of a tissue comprises direct antioxidant effects and that of the antioxidant enzymes increased by secondary mechanisms. In our study, the broccoli-derived isothiocyanate SFN, having no direct antioxidant properties, produced the lowest increase in jejunal TEAC compared to group Con. From this fact, it can be concluded that the increase in jejunal TEAC in group SFN mainly bases on the induction of ARE-regulated antioxidant enzymes. For Cuo showing an intermediate effect on jejunal TEAC, it can be assumed that both, its moderate direct antioxidant effect and the powerful induction of ARE-regulated antioxidant enzymes by ar-turmerone ${ }^{(23,58,59)}$ have contributed to jejunal TEAC modulation (Fig. 2). Oo and To contain high concentrations of the antioxidant phenolic terpenes carvacrol and thymol $^{(14)}$. In contrast, both oils have induced ARE-regulated enzymes only moderately. Therefore, the high jejunal TEAC values of Oo and To may mainly result from their high carvacrol and thymol content (Fig. 2). To complicate matters, Ro had the highest TEAC value within the labiatae oils. Additionally, Ro powerfully induced intestinal ARE-regulated genes (Table 7; jejunum, colon). However, its influence on jejunal TEAC was not stronger than that of Oo and To. This conflicting result could have two causes: on the one hand, the nonantioxidant epoxy-terpene 1,8 cineole $^{(58)}$ may have produced a strong induction of ARE-regulated antioxidant enzymes. On the other hand, Ro additionally contains small amounts of the phenolic diterpenes carnosic acid, carnosol and epirosmanol coming along with a high direct antioxidant activity ${ }^{(14,60)}$, which may limit the further induction of ARE-regulated antioxidant enzymes. In summary, our data showed a differentiated response of intestinal ARE-regulated genes to dietary treatment with the phytogenic additives SFN, Cuo, Oo, To and Ro. Future studies with tissue cultures and other farm animal species should focus on the examination of the individual xenobiotic-and antioxidant enzyme induction pattern of $\mathrm{EO}$, and in particular, on the examination of their pure main terpenes and of SFN. In those studies, the added concentration of the oils should be standardised to their main terpenes. The results of those investigations may contribute to the creation of new and optimised mixtures of phytogenic feed additives.

\section{Nuclear factor erythroid 2-related factor 2, antioxidant response element-regulated xenobiotic- and antioxidant enzymes, Trolox equivalent antioxidant capacity and thiobarbituric acid-reactive substances in the liver}

In contrast to our expectations and to data from other studies $^{(25,61,62)}$, SFN and Cuo, the reference substances in our experiment, as well as the labiatae oils, generally reduced the expression of ARE-regulated genes in the liver (Table 7, liver). Nevertheless, data from other trials feeding diets supplemented with curcumin, quercetin and catechin to mice and rats support our findings regarding a down-regulation of xenobiotic- and antioxidant enzymes in the liver ${ }^{(63,64)}$. This effect may have two reasons:

(1) The dietary concentration of both reference additives was too low to produce an induction of ARE-regulated genes also in the liver.

(2) The antioxidant protection achieved by the induction of ARE-regulated genes in the intestine acted as a barrier and protected the organism against the uptake of toxic xenobiotics and against oxidative stress.

However, the second hypothesis seems to be more plausible, since we found a distinct up-regulation of SOD- and GPx enzyme activity by all phytogenic feed additives compared to the control in jejunal mucosa (Table 8). Intestinal GPx activity, measured with $\mathrm{H}_{2} \mathrm{O}_{2}$ as the substrate, comprises the activity of GPx1 and GPx2. GPx2 is an unusual selenoprotein, induced by both, a sufficient selenium status and by $\mathrm{Nrf2} 2^{(65,66)}$. Both peroxidases underlie a coordinated regulation. In the case of lacking GPx2 activity, GPx1 is upregulated to compensate reduced peroxide detoxification ${ }^{(67)}$. Numerous studies have demonstrated that the loss of both enzymes promotes the development of chronic inflammatory intestinal diseases. Moreover, it has been shown that GPx2 blocks the up-regulation of the proinflammatory inducible cyclo-oxygenase 2. Further, GPx2 impedes the aquaporinmediated absorption of peroxides into the organism ${ }^{(68-72)}$.

Our second hypothesis that the increased intestinal barrier against pro-oxidants and inflammatory stress protects peripheral organs like the liver from oxidative stress is further supported by our findings for $\mathrm{Nrf}^{(73)}$ (Fig. 1(A) and (B)), SOD (Table 8), GPx1 (Table 8), TEAC (Fig. 2) and TBARS (Fig. 3). The coincident down-regulation of active Nrf2 (Fig. 1(A) and (B)) and xenobiotic- and antioxidant enzymes (Table 7 , liver) on the one hand, and higher TEAC values 
(Fig. 2) accompanied by a reduced, provoked lipid peroxidation (Fig. 3) of all chickens receiving a phytogenic additive on the other, suggest that the livers of supplemented broilers had an increased antioxidative capacity and reduced oxidative stress, making the further induction of antioxidant enzymes dispensable ${ }^{(63,64)}$. This particular result was also supported by the finding that protein abundance of ubiquitinated Nrf2 was significantly higher in broilers fed diets with phytogenic additives than in Con broilers (Fig. 1(A) and (B)). Contrarily it can be assumed that the livers of untreated Con broilers were exposed to higher oxidative stress, as indicated by the highest protein abundance of active Nrf2 and the lowest of ubiquitinated Nrf2. This, in turn, explains the higher expression of ARE-regulated xenobiotic-and antioxidant enzymes in Con broilers ${ }^{(73)}$.

That feeding phytogenic feed additives protects peripheral organs from oxidative stress is confirmed by results from other studies reporting on reduced lipid peroxidation and increased storage stability of broiler meat and fat ${ }^{(74-76)}$

In contradiction to our results, a study with broilers found a distinct up-regulation of liver ARE-regulated genes ( $A F A R$, $E P H X 1)$ due to feeding diets with turmeric powder. However, this response was triggered only by feeding aflatoxin simultaneously ${ }^{(45)}$. From this fact it can be concluded once again that the regulation of liver ARE genes by phytogenic substances presumably depends largely on the exposure of an organism to toxic substances and oxidative stress. In contrast, an optimum protection against oxidative stress counteracts the further induction of ARE-regulated xenobiotic- and antioxidant enzymes in peripheral organs ${ }^{(63,64)}$.

An issue that should be addressed at the end of the discussion is the regulation of phase II, I and III enzymes in a unidirectional manner as analysed in our study (Table 7, liver). This aspect is very important to keep the balance between the single stages of xenobiotic metabolism ${ }^{(77)}$ and to prevent the organism from damage. The simultaneous down-regulation of Cyp1A1 with an important function in mycotoxin activation $^{(78)}$, of the xenobiotic-and antioxidant phase II enzymes investigated ${ }^{(79)}$, and of ABCC2 responsible for the excretion of conjugated mycotoxin metabolites ${ }^{(80)}$, is a further indicator of a reduced exposure of the liver to toxic metabolites and oxidative stress. In summary, our results for the liver suggest that the induction of jejunal ARE-regulated genes and the increase in jejunal TEAC in the small intestine by phytogenic feed additives seem to act as a barrier against oxidative stress in the organism ${ }^{(71,72)}$. This protective function of essential oils and of broccoli extract is also of particular interest for human nutrition and with regard to inflammatory bowel disease in humans ${ }^{(68,69,71)}$, since we have used chickens as a single-stomached animal species in our study.

\section{Conclusions}

(1) On the one hand, our study confirmed results from the literature that phytogenic feed additives do not merely act as growth promoters under conditions without an infectious or toxic challenge.
(2) On the other hand, our results have demonstrated for the first time that broccoli extract, Cuo and the labiatae oils of oregano, thyme and rosemary influence the expression of ARE-regulated xenobiotic- and antioxidant enzymes. The up-regulation of these genes in the intestine seems to build a barrier against oxidative stress in the organism. In particular, the up-regulation of ARE-regulated genes in the small intestine may represent an attractive and new mechanism by which phytogenic feed additives improve the intestinal and general health of farm animals.

(3) However, different regulation patterns of the single phytogenic substances demonstrate the necessity for future research with regard to this issue. Understanding the different regulation patterns of single phytogenic feed additives may contribute to the development of optimised combinations of phytogenic substances in animal nutrition and to the use of these substances as dietary supplements for humans.

(4) Moreover, we have tested for the first time a broccoli sprouts extract containing SFN as a phytogenic feed additive in animal nutrition. Compared to the other additives tested, SFN did not show significant negative effects on the performance parameters under well-controlled housing conditions without a microbial or toxic challenge. Moreover, broccoli extract acted as a modulator of the aforementioned ARE-regulated genes. For this reason, broccoli extract, currently permitted only as a dietary supplement for humans, has turned out to be an attractive phytogenic feed additive for use in the future.

\section{Acknowledgements}

The present study was supported by the $H$. Wilhelm Schaumann Foundation, Hamburg by the provision of a non-recurring donation for the study and by funding Dipl. troph. Kristin Mueller with a doctoral scholarship. We thank Devakumari Hiller (Jarrow Deutschland GmbH, Berlin, Germany) for arranging the contact with Jarrow L. Rogovin from Jarrow Formulas, Los Angeles, CA, USA, who provided us with the broccoli seed extract. Further thanks are addressed to Dostofarm GmbH (Westerstede, Germany) for providing us with the Oo. Moreover, we thank our stockmen Olaf Hoedel and Detlev Barth for their help with the diet preparation, animal care and organ sampling. Thanks are also addressed to our Master's degree students Anke Markert and Kathrin Sinningen for their help with the analyses within the scope of their Master's theses. The contributions of the authors were as follows: K. M. assisted in planning the trial and blending the diets. Further, she participated in the broilers' care and organ sampling. She carried out all laboratory analyses and supervised the Master's degree students who had supported her with the analyses. Besides, K. M. carried out the data evaluation, other than writing voluminous sections of the manuscript. N. M. B. assisted K. M. in the laboratory analyses and helped in the preparation of the tables. H. K. was responsible for calculating the exact composition of the diets. A. S. M. planned the trial and participated in organ sampling and 
analyses. Further, he had drafted the applications for obtaining the licence for the animal study and the certificate of exemption for using the broccoli sprouts extract as a feed. A. S. M. contributed to supervising the data evaluation and manuscript writing. All authors declare that they have no conflicts of interest.

\section{References}

1. Windisch W, Schedle K, Plitzner C, et al. (2008) Use of phytogenic products as feed additives for swine and poultry. J Anim Sci 86, E140-E148.

2. Halle I, Thomann R, Bauermann U, et al. (2004) Einfluss einer gestaffelten Supplementierung von Kräutern oder ätherischen Ölen auf Wachstum und Schlachtkörpermerkmalen beim Broiler (Effects of adding graded amounts of herbs or essential oils to broiler diets on performance and carcass characteristics). Landbauforschung Völkenrode $\mathbf{5 4}$, 219-229

3. Basmacioğlu Malayoğlu $\mathrm{H}$, Baysal S, Misirlioğlu Z, et al. (2010) Effects of oregano essential oil with or without feed enzymes on growth performance, digestive enzyme, nutrient digestibility, lipid metabolism and immune response of broilers fed on wheat-soybean meal diets. Br Poult Sci 51, 67-80.

4. Westendrap H, Klaus P, Halle I, et al. (2006) Effect of carvacrol, $y$-terpinene and P-cymene-7-ol in broiler feed on growth traits and N-metabolism. FAL Agric Res 3/4, 149-157.

5. Cross DE, McDevitt RM, Hillman K, et al. (2007) The effect of herbs and their associated essential oils on performance, dietary digestibility and gut microflora in chickens from 7 to 28 days of age. Br Poult Sci $\mathbf{4 8}, 496-506$.

6. Burt SA, Vlielander R, Haagsman HP, et al. (2005) Increase in activity of essential oil components carvacrol and thymol against Escherichia coli $\mathrm{O} 157: \mathrm{H} 7$ by addition of food stabilizers. J Food Prot 68, 919-926.

7. Burt SA, van der Zee R, Koets AP, et al. (2007a) Carvacrol induces heat shock protein 60 and inhibits synthesis of flagellin in Escherichia coli $\mathrm{O} 157 \mathrm{H} 7$. Appl Environ Microbiol 73, 4484-4490.

8. Burt SA, Fledderman MJ, Haagsman HP, et al. (2007b) Inhibition of Salmonella enterica serotype Enteritidis on agar and raw chicken by carvacrol vapour. Int J Food Microbiol 119, 346-350

9. Kiliç T (2006) Analysis of essential oil composition of Thymbra spicata var spicata antifugal, antibacterial and antimycobacterial activities. Z Naturforsch 61, 324-328.

10. Fabian D, Sabol M, Domaracká K, et al. (2006) Essential oils - their antimicrobial activity against Escherichia coli and effect on intestinal cell viability. Toxicol In Vitro 20, $1435-1445$.

11. Horosová K, Bujnáková D \& Kmet V (2006) Effect of oregano essential oil on chicken lactobacilli and E coli. Folia Microbiol (Praha) 51, 278-280.

12. Tiihonen K, Kettunen H, Bento MH, et al. (2010) The effect of feeding essential oils on broiler performance and gut microbiota. Br Poult Sci 51, 381-392.

13. Jamroz D, Wiliczkiewicz A, Wertelecki T, et al. (2005) Use of active substances of plant origin in chicken diets based on maize and locally grown cereals. Br Poult Sci 46, 485-493.

14. Shan B, Cai YZ, Sun M, et al. (2005) Antioxidant capacity of 26 spice extracts and characterization of their phenolic constituents. J Agric Food Chem 53, 7749-7759.
15. Negi PS, Jayaprakasha GK, Jagan Mohan Rao L, et al. (1999) Antibacterial activity of turmeric oil a byproduct from curcumin manufacture. Agric Food Chem 47, 4297-4300.

16. Sacchetti G, Maietti S, Muzzoli M, et al. (2005) Comparative evaluation of 11 essential oils of different origin as functional antioxidants, antiradicals and antimicrobials in foods. Food Chem 91, 621-632.

17. Clarke JD, Dashwood RH \& Ho E (2008) Multi-targeted prevention of cancer by sulforaphane. Cancer Lett 269, 291-304.

18. Shapiro TA, Fahey JW, Dinkova-Kostova AT, et al. (2006) Safety, tolerance, and metabolism of broccoli sprout glucosinolates and isothiocyanates a clinical phase I study. Nutr Cancer 55, 53-62.

19. Aires A, Mota VR, Saavedra MJ, et al. (2009) The antimicrobial effects of glucosinolates and their respective enzymatic hydrolysis products on bacteria isolated from human intestinal tract. J Appl Microbiol 106, 2086-2095.

20. Chauhan DP (2002) Chemotherapeutic potential of curcumin for colorectal cancer. Curr Pharm Des 8, 1695-1706.

21. Iqbal M, Sharma SD, Okazaki Y, et al. (2003) Dietary supplementation of curcumin enhances antioxidant and phase II metabolizing enzymes in ddY male mice possible role in protection against chemical carcinogenesis and toxicity. Pharmacol Toxicol 92, 33-38.

22. Petri N, Tannergren C, Holst B, et al. (2003) Absorption/ metabolism of sulforaphane and quercetin, and regulation of phase II enzymes, in human jejunum in vivo. Drug Metab Dispos 31, 805-813.

23. Miyakoshi M, Yamaguchi Y, Takagaki R, et al. (2004) Hepatoprotective effect of sesquiterpenes in turmeric. Biofactors 21, 167-170.

24. Yoxall V, Kentish P, Coldham N, et al. (2005) Modulation of hepatic cytochromes P450 and phase II enzymes by dietary doses of sulforaphane in rats: implications for its chemopreventive activity. Int J Cancer 117, 356-362.

25. Hu R, Xu C, Shen G, et al. (2006) Gene expression profiles induced by cancer chemopreventive isothiocyanate sulforaphane in the liver of $\mathrm{C} 57 \mathrm{BL} / 6 \mathrm{~J}$ mice and $\mathrm{C} 57 \mathrm{BL} / 6 \mathrm{~J} / \mathrm{Nrf} 2$ $(-/-)$ mice. Cancer Lett 18, 170-192.

26. Gowda NK, Ledoux DR, Rottinghaus GE, et al. (2008) Efficacy of turmeric (Curcuma longa), containing a known level of curcumun, and a hydrated sodium calcium aluminosilicate to ameliorate the adverse effects of aflatoxin in broiler chicks. Poult Sci 87, 1125-1130.

27. Hong F, Freeman ML \& Liebler DC (2005) Identification of sensor cysteines in human Keap1 modified by the cancer chemopreventive agent sulforaphane. Chem Res Toxicol 18, 1917-1926.

28. Surh YN (2008) NF-кB and Nrf2 as potential chemopreventive targets of some anti-inflammatory and antioxidative phytonutrients with anti-inflammatory and antioxidative activities. Asia Pac J Clin Nutr 17, 269-272.

29. Sasaki K, Wada K, Tanaka Y, et al. (2005) Thyme (Thymus vulgaris $\mathrm{L}$ ) leaves and its constituents increase the activities of xenobiotic-metabolizing enzymes in mouse liver. $J$ Med Food 8, 184-189.

30. Society for Laboratory Animal Science (2006) Fütterungskonzepte und - methoden in der Versuchstierhaltung und im Tierversuch (Hubn) (Feeding Concepts and Feeding Methods for Experimental Animals). Stuttgart: Ferdinand Enke Verlag.

31. Gesellschaft für Ernährungsphysiologie (1999) Empfehlungen zur Energie- und Nährstoffversorgung der Legehennen und Masthühner (Broiler) (Energy and Nutrient Requirements of Laying Hens and Broilers). Frankfurt: DLG-Verlag. 
32. NRC (1994) National Research Council: Nutrient Requirements of Poultry, 9th revised ed. Washington, DC: National Academy Press.

33. Livak KJ \& Schmittgen TD (2001) Analysis of relative gene expression data using real-time quantitative PCR and the 2(-Delta Delta C(T)). Methods 25, 402-408.

34. Bustin SA, Benes V, Garson JA, et al. (2009) The MIQE guidelines: minimum information for publication of quantitative real-time PCR experiments. Clin Chem 55, 611-622.

35. Vandesompele J, De Preter K, Pattyn F, et al. (2002) Accurate normalization of real-time quantitative RT-PCR data by geometric averaging of multiple internal control genes. Genome Biol 3, 1-12.

36. Hosseini A, Sauerwein H \& Mielenz M (2010) Putative reference genes for gene expression studies in propionate and $\beta$-hydroxybutyrate treated bovine adipose tissue explants. J Anim Physiol Anim Nutr (Berl) 94, 78-84.

37. Olsvik PA, Lie KK, Mykkeltvedt E, et al. (2008) Pharmacokinetics and transcriptional effects of the anti-salmon lice drug emamectin benzoate in Atlantic salmon (Salmo salar L.). BMC Pharmacol 11, 8-16.

38. Marklund SL \& Marklund G (1974) Involvement of superoxide anion radical in the autoxidation of pyrogallol and a convenient assay of superoxide dismutase. Eur J Biochem 253, 1848-1858.

39. Lawerence RA \& Burk RF (1976) Glutathione peroxidase activity in selenium-deficient rat liver. Biochem Biophys Res Commun 71, 952-957.

40. Miller NJ, Rice-Evans C, Davies MJ, et al. (1993) A novel method for measuring antioxidant capacity and its application to monitoring the antioxidant status in premature neonates. Clin Sci (Lond) 84, 407-412.

41. Wang CC, Chu CY, Chu KO, et al. (2004) Trolox-equivalent antioxidant capacity assay versus oxygen radical absorbance capacity assay in plasma. Clin Chem 50, 952-954.

42. Wong SHY, Knight JA, Hopfer SM, et al. (1987) Lipoperoxides in plasma as measured by liquid-chromatographic separation of malondialdehyde-thiobarbituric acid adduct. Clin Chem 33, 214-220.

43. Bradford MM (1976) A rapid sensitive method for the quantitation of microgram quantities of protein utilizing the principle of protein-dye binding. Anal Biochem 72, 248-254.

44. Laemmli UK (1970) Cleavage of structural proteins during the assembly of the head of bacteriophage T4. Nature $\mathbf{2 2 7}$, 680-685.

45. Yarru LP, Settivari RS, Gowda NKS, et al. (2009) Effects of turmeric (Curcuma longa) on the expression of hepatic genes associated with biotransformation, antioxidant, and immune systems in broiler chicks fed aflatoxin. Poult Sci $\mathbf{8 8}, 2620-2627$.

46. Vieira SL, Olmos AR, Berres J, et al. (2007) Responses of female broilers from two strain crosses to diets with differing ideal protein profiles. Ciênc Rural 37, 1753-1759.

47. Gowda NK, Ledoux DR, Rottinghaus GE, et al. (2009) Antioxidant efficacy of curcuminoids from turmeric (Curcuma longa L.) powder in broiler chickens fed diets containing aflatoxin B1. Br J Nutr 102, 1629-1634.

48. McMillan M, Spinks EA \& Fenwick GR (1986) Preliminary observations on the effect of dietary brussels sprouts on thyroid function. Hum Toxicol 5, 15-19.

49. Giannenas I, Florou-Paneri $\mathrm{P}$, Papazahariadou $\mathrm{M}$, et al. (2003) Effect of dietary supplementation with oregano essential oil on performance of broilers after experimental infection with Eimeria tenella. Arch Tierernabr 57, 99-106.
50. Clarke JO \& Mullin GE (2008) A review of complementary and alternative approaches to immunomodulation. Nutr Clin Pract 23, 49-62.

51. Li F, Hullar MAJ, Beresford SAA, et al. (2011) Variation of glucoraphanin metabolism in vivo and ex vivo by human gut bacteria. Br J Nutr 106, 408-416.

52. Pool-Zobel B, Veeriah S \& Böhmer FD (2005) Modulation of xenobiotic metabolising enzymes by anticarcinogens focus on glutathione $S$-transferase and their role as targets of dietary chemoprevention in colorectal carcinogenesis. Mutat Res 591, 74-92.

53. Johnson JJ \& Mukhtar H (2007) Curcumin for chemoprevention of colon cancer. Cancer Lett 255, 170-181.

54. Yeh CT, Chiu HF \& Yen GC (2009) Protective effect of sulforaphane on indomethacin-induced cytotoxicity via heme oxygenase-1 expression in human intestinal Int 407 cells. Mol Nutr Food Res 53, 1166-1176.

55. Joshi J, Ghaisas S, Vaidya A, et al. (2003) Early human safety study of turmeric oil (Curcuma longa oil) administered orally in healthy volunteers. $J$ Assoc Physicians India 51, 1055-1060.

56. Arnér ES \& Holmgren A (2000) Physiological functions of thioredoxin and thioredoxin reductase. Eur J Biochem 267 , 6102-6109.

57. Wang X, Tomso DJ, Chorley BN, et al. (2007) Identification of polymorphic antioxidant response elements in the human genome. Hum Mol Genet 16, 1188-1200.

58. Jäger S, Scheffler A \& Schmellenkamp H (2006) Pharmakologie ausgewählter Terpene (Pharmacology of selected terpenes). Pharmazeutische Zeitung. http://www.pharma zeutische-zeitung.de/index.php?id $=1354$ (last available 16 March 2011) (online 22).

59. Anonymous (2011) Evonik Industries product information (no authors listed). TEGO ${ }^{\circledR}$ Turmerone: the distilled fraction of turmeric oil extracted from the roots of Curcuma longa by supercritical carbon dioxide. http://www.centerchem.com/ PDFs/TEGO\%20Turmerone\%20Tech\%20Lit\%200208.pdf (last available 16 March 2011).

60. Erkan N, Ayranci G \& Ayranci E (2008) Antioxidant activities of rosemary (Rosmarinus officinalis L) extract, blackseed (Nigella sativa L.) essential oil, carnosic acid, rosmarinic acid and sesamol. Food Chem 110, 76-82.

61. Lii CK, Liu KL, Cheng YP, et al. (2010) Sulforaphane and alpha-lipoic acid upregulate the expression of the pi class of glutathione $S$-transferase through c-jun and Nrf2 activation. J Nutr 140, 885-892.

62. El-Ashmawy IM, Ashry KM, El-Nahas AF, et al. (2006) Protection by turmeric and myrrh against liver oxidative damage and genotoxicity induced by lead acetate in mice. Basic Clin Pharmacol Toxicol 98, 32-37.

63. Wiegand H, Boesch-Saadatmandi C, Regos I, et al. (2009) Effects of quercetin and catechin on hepatic glutathione- $S$ transferase (GST), NAD(P)H quinone oxidoreductase 1 (NQO1), and antioxidant enzyme activity levels in rats. Nutr Cancer 61, 717-722.

64. Schrader C, Schiborr C, Frank J, et al. (2011) Curcumin induces paraoxonase 1 in cultured hepatocytes in vitro but not in mouse liver in vivo. Br J Nutr 105, 167-170.

65. Brigelius-Flohé R, Müller C, Menard J, et al. (2001) Functions of GI-GPx lessons from selenium-dependent expression and intracellular localization. Biofactors 14, 101-106.

66. Müller M, Banning A, Brigelius-Flohé R, et al. (2010) Nrf2 target genes are induced under marginal seleniumdeficiency. Genes Nutr 5, 297-307. 
67. Florian S, Krehl S, Loewinger M, et al. (2010) Loss of GPx2 increases apoptosis, mitosis, and GPx1 expression in the intestine of mice. Free Radic Biol Med 49, 1694-1702.

68. Esworthy RS, Kim BW, Larson GP, et al. (2011) Colitis locus on chromosome 2 impacting the severity of early-onset disease in mice deficient in GPX1 and GPX2. Inflamm Bowel Dis 17, 1373-1386.

69. Esworthy RS, Aranda R, Martín MG, et al. (2001) Mice with combined disruption of Gpx1 and Gpx2 genes have colitis. Am J Physiol Gastrointest Liver Physiol 281, G848-G855.

70. Banning A, Kipp A, Schmitmeier S, et al. (2008) Glutathione peroxidase 2 inhibits cyclooxygenase-2-mediated migration and invasion of HT-29 adenocarcinoma cells but supports their growth as tumors in nude mice. Cancer Res 68, 9746-9753.

71. Te Velde AA, Pronk I, de Kort F, et al. (2008) Glutathione peroxidase 2 and aquaporin 8 as new markers for colonic inflammation in experimental colitis and inflammatory bowel diseases: an important role for $\mathrm{H}_{2} \mathrm{O}_{2}$ ? Eur J Gastroenterol Hepatol 20, 555-560.

72. Wingler K, Müller C, Schmehl K, et al. (2000) Gastrointestinal glutathione peroxidase prevents transport of lipid hydroperoxides in CaCo-2 cells. Gastroenterology 119, 420-430.

73. Itho K, Miramura J \& Yamamoto M (2010) Discovery of the negative regulator of Nrf2, Keap1: a historical overview. Antioxid Redox Signal 13, 1665-1678.

74. Lopez-Bote CJ, Gray JI, Gomaa EA, et al. (1998) Effect of dietary administration of oil extracts from rosemary and sage on lipid oxidation in broiler meat. Br Poult Sci 39, 235-240.

75. Botsoglou NA, Florou-Paneri P, Christaki E, et al. (2002) Effect of dietary oregano essential oil on performance of chickens and on iron-induced lipid oxidation of breast, thigh and abdominal fat tissues. Br Poult Sci $\mathbf{4 3}$, 223-230.

76. Mirshekar R, Dastar B \& Shabanpour B (2009) Effect of rosemary, echinacea, green tea extracts and ascorbic acid on broiler meat quality. Pak J Biol Sci 12, 1069-1074.

77. Patterson AD, Gonzalez FJ \& Idle JR (2010) Xenobiotic metabolism a view through the metabolometer. Chem Res Toxicol 23, 851-860.

78. Diaz GJ, Murcia HW \& Cepeda SM (2010) Bioactivation of aflatoxin B1 by turkey liver microsomes: responsible cytochrome P450 enzymes. Br Poult Sci 51, 828-837.

79. McWalter GK, Higgins LG, McLellan LI, et al. (2004) Transcription factor $\mathrm{Nrf} 2$ is essential for induction of $\mathrm{NAD}(\mathrm{P}) \mathrm{H}$ :quinone oxidoreductase 1 , glutathione $S$-transferases, and glutamate cysteine ligase by broccoli seeds and isothiocyanates. J Nutr 134, 3499S-3506S.

80. Videmanna B, Mazallona M, Prouillaca C, et al. (2009) $\mathrm{ABCC} 1, \mathrm{ABCC} 2$ and $\mathrm{ABCC} 3$ are implicated in the transepithelial transport of the myco-estrogen zearalenone and its major metabolites. Toxicol Lett 190, 215-223 